\title{
Article \\ Sedimentary Characteristics Analysis and Sedimentary Facies Prediction of Jurassic Strata in the Northwest Margin of Junggar Basin-Covering the W105 Well Region in the Wuerhe Area
}

\author{
Shiqi Liu ${ }^{1}$ (D) and Yuyang Liu ${ }^{1,2,3, *(D)}$ \\ 1 School of Earth and Space Sciences, Peking University, Beijing 100871, China; liushiqi17@pku.edu.cn \\ 2 PetroChina Research Institute of Petroleum Exploration and Development, Beijing 100083, China \\ 3 China National Shale Gas Research \& Development (Experiment) Center, Langfang 065007, China \\ * Correspondence: yuyangliu@pku.edu.cn
}

check for

updates

Citation: Liu, S.; Liu, Y. Sedimentary

Characteristics Analysis and

Sedimentary Facies Prediction of

Jurassic Strata in the Northwest

Margin of Junggar Basin-Covering

the W105 Well Region in the Wuerhe

Area. Minerals 2022, 12, 68. https://

doi.org/10.3390/min12010068

Academic Editors: Monika Ivandic

and Fengjiao Zhang

Received: 29 November 2021

Accepted: 3 January 2022

Published: 5 January 2022

Publisher's Note: MDPI stays neutral with regard to jurisdictional claims in published maps and institutional affiliations.

Copyright: (C) 2022 by the authors. Licensee MDPI, Basel, Switzerland. This article is an open access article distributed under the terms and conditions of the Creative Commons Attribution (CC BY) license (https:// creativecommons.org/licenses/by/ $4.0 /)$.

\begin{abstract}
As the northwestern area of the Junggar Basin is a key area for oil and gas exploration, the sedimentary facies of the Jurassic formations in the Wuerhe area has long been a focus of research. The target strata are Jurassic strata, including five formations: the Lower Jurassic Badaowan and Sangonghe, the Middle Jurassic Xishanyao and Toutunhe and the Upper Jurassic Qigu. Disputes over the are sedimentary facies division exist in this area. Considering the W105 well region in this area as an example, the overall sedimentary facies of single-well logging facies is analyzed and then expanded to two cross-sections and characterized. Based on previous studies, a detailed overview of the regional stratigraphy is obtained by well logs and other data. Then, two cross-sections are selected and analyzed. The single-well and continuous-well facies of 10 wells in the sections are analyzed to grasp the sand bodies' spatial distribution. Finally, a planar contour map of the net to gross ratio is mapped to analyze the sources and the distribution of the sand bodies in each period. The sedimentary facies map is also mapped to predict the sedimentary evolution. The results show that the sedimentary facies of the Badaowan Formation in the study area was an underwater distributary channel of the fan-delta front, and the sand body spread continuously from northwest to southeast. The Sangonghe Formation entered a lake transgression period with a rising water level, at which time shore-shallow lacustrine deposits were widespread throughout the region. The period of the Xishanyao Formation entered a regression period, the northwest region was tectonically uplifted, and the central and southeastern regions facies were dominated by the fan-delta front and shallow lacustrine. During the Toutunhe Formation period, the northwest region continued to uplift and was dominated by delta plain facies. During the period of the Qigu Formation, the thickness of stratigraphic erosion reached its maximum, and the non-erosion area of the study area was mainly deposited by the fan-delta plain. Overall, the Jurassic system in the W105 well area is a fan delta-lacustrine-fan delta sedimentary system.
\end{abstract}

Keywords: Junggar Basin; Jurassic; net to gross ratio; sedimentary facies; fan-delta; lacustrine

\section{Introduction}

As a large petroliferous basin in Northwest China with an area of $130,900 \mathrm{~km}^{2}$, the Junggar Basin has been undergoing hydrocarbon exploration since the mid-20th century [1]. After nearly half a century of exploration, both its oil and gas reserves have proven to be significant. The main reservoirs in the basin are from the late Paleozoic and Mesozoic, among which the Jurassic reservoirs distributed in Karamay, Wuerhe and other areas in the northwest margin are viewed as important production layers [2-4]. With a high degree of exploration, the northwestern margin area has many exploratory wells, covering an area of more than $2100 \mathrm{~km}^{2}$ on 2D seismic data and more than $1500 \mathrm{~km}^{2}$ on 3D seismic data [5].

Sedimentary facies control the distribution of oil and gas reservoirs. In addition, the distribution of sedimentary facies belts has a controlling effect on the aggregation 
of gas and oil in lithologic reservoirs. Studying the characteristics of various types of sedimentary facies not only has key theoretical significance but also provides a basis for further exploration and development [5,6]. Well W105 has great potential of exploring the study area sedimentary facies. The study of Jurassic sedimentation within the control range of Well W105 in the Wuerhe area of Fengcheng will be valuable to understand the distribution and prediction of local sedimentary facies in the Fengcheng area. As large issues can be understood through small issues, this study will help us to predict the distribution of Jurassic dominant sedimentary facies in the Fengcheng area.

The target strata in the study area are Jurassic strata, as shown in Table 1, including the Lower Jurassic Badaowan Formation $\left(J_{1} b\right)$ and Sangonghe Formation $\left(J_{1} s\right)$. Two main strata developed in the Middle Jurassic, specifically the Xishanyao Formation $\left(\mathrm{J}_{2} \mathrm{x}\right)$ in the lower portion and the Toutunhe Formation $\left(\mathrm{J}_{2} \mathrm{t}\right)$ in the upper portion. In Upper Jurassic, two sets of strata mainly developed in the area - the Qigu Formation and Turpan Formation-but the strata in the study area are missing due to crustal uplift, so only Qigu Formation $\left(\mathrm{J}_{3} \mathrm{q}\right)$ is developed.

Table 1. General stratigraphy of the study area.

\begin{tabular}{cccc}
\hline \multirow{2}{*}{ System } & Series & Stage & Code \\
\hline \multirow{3}{*}{ Jurassic } & Upper & Badaowan Formation & $\mathrm{J}_{1} \mathrm{~b}$ \\
& Sangonghe Formation & $\mathrm{J}_{1} \mathrm{~s}$ \\
\cline { 2 - 4 } & \multirow{2}{*}{ Middle } & Xishanyao Formation & $\mathrm{J}_{2} \mathrm{x}$ \\
& Lower & Toutunhe Formation & $\mathrm{J}_{2} \mathrm{t}$ \\
\cline { 2 - 4 } & Qigu Formation & $\mathrm{J}_{3} \mathrm{q}$ \\
\hline
\end{tabular}

Regarding the Jurassic strata of the study area, there are many disputes over the division of sedimentary facies. Previous study suggests that the Jurassic sedimentary facies in the Fengcheng area mainly includes braided fluvial facies, braided fluvial deltas and lacustrine facies [7]. Moreover, the complex tectonic background caused by regional tectonic movements at the end of the Jurassic period resulted in rapid facies belt changes, with different sedimentary facies reflected at different locations. However, in the prediction of sedimentary facies of the Sangonghe Formation of the Upper Jurassic, there have always been some disputes about whether they are shallow lacustrine facies, braided fluvial facies or (fan) delta facies [7]. Studies have presented different views on the prediction of sedimentary facies. Some studies have stated that the sedimentary facies of the Qigu Formation was braided fluvial depositions in the study area [8], with microfacies such as channels, central bars, floodplains and natural levees.

Firstly, in this study, according to core logging, cutting logging and other well logging data in the W105 well area, the single-well logging facies model and the sedimentary facies model of the vertical span of continuous wells are established. Then, according to the net to gross ratio of each section of the single well, planar views of the net to gross ratio of each group are plotted; on this basis, the sedimentary facies model map of different periods is drawn in combination with the logging facies. Finally, based on the above findings, the planar distribution of the Jurassic strata sedimentary facies in the study area is predicted and studied. Combined with previous studies, we believe that the Qigu Formation is a fandelta deposit and a fan-delta plain subfacies. Furthermore, we believe that the Sangonghe Formation in the study area belongs to the shore-shallow lacustrine sedimentary facies.

\section{Regional Geological Background}

The Fengcheng oil field is located on the northwestern edge of the Junggar Basin, approximately $130 \mathrm{~km}$ away from the Karamay city center. Its tectonic position is located in the upper plate of the Xiahong North Fault of the Wuxia Fault Zone, bounded by the North Ulanlinge Fault and adjacent to the northern slope zone of the Mahu Depression in the south. The oil field runs approximately $13 \mathrm{~km}$ from north to south and $24 \mathrm{~km}$ from east 
to west, at approximately $300 \mathrm{~m}$ above sea level. It is bordered by Hala'alat Mountain in the north, the town of Wuerhe in the west, and Xia Zijie in the east. Differential weathering in the work area is severe, with altitudes ranging from 298-353 m, annual temperatures ranging from -40 to $40{ }^{\circ} \mathrm{C}$, low rainfall and high evaporation; it has a continental arid climate [1-8].

The Junggar Basin is an important inland basin in Western China. The northwestern margin area is located between the Junggar Massif and the West Junggar Fold Mountain System, and Junggar Basin is also one of the main gas and oil-bearing areas in the basin [7-9]. It belongs to the key development area of the Xinjiang oil fields, with great oil exploration potential. It has been the core area for oil exploration work in Xinjiang in recent years, so many oil fields have been developed in this area, with much more to offer [9]. The tectonic type of the northwest boundary of the Junggar Basin is dominated by large thrust structural fault zones, and there are a series of secondary structural units developed from south to north on the northwestern boundary of the basin (Figure 1), which are mainly divided into three fracture zones according to their geographical locations and surrounding towns: the Hongshanzui-Chepaizi Fault Zone (Hong-Che Fault Zone), the Karamay-Baikouquan Fault Zone (Ke-Bai Fault Zone) and the Wuerhe-Xiazijie Fault Zone (Wu-Xia Fault Zone). There are three main fault zones in the Wuerhe-Xiazijie Fault Zone (Wu-Xia Fault Zone). On the east side of the fault zone, there are secondary structural units of depression and uplift, mainly represented by the Shawan depression, the Mahu depression and the Zhongguai uplift.
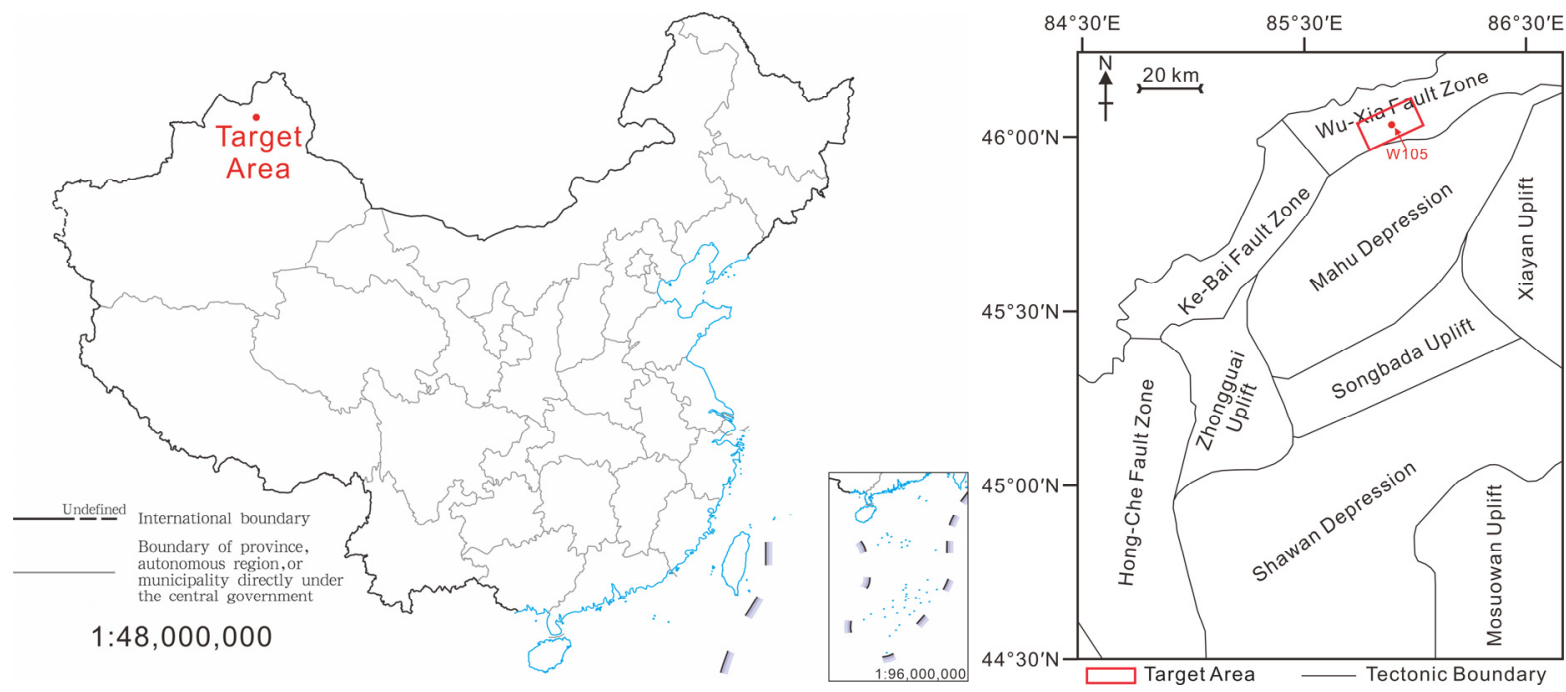

Figure 1. Structural and geographic location map of the study area.

The origin of the large overthrusting tectonic zone in the northwestern margin is considered by different scholars to have different possible interpretations. One of them was formed by the subduction and even collision of the oceanic crust where the Turpan Junggar plate is located. A series of subduction events resulted in foreland-type sedimentary depressions and lateral uplift belts; that is, large structural fault belts formed from Chepaizi to Hongshanzui in the Xiazijie area [10].

The tectonic activity in the northwestern margin was more intense in the late Paleozoic period, and when the northwestern margin entered the early stage of the Yanshan Movement, the tectonic intensity dropped off greatly from the previous period despite the influence of the Yanshan Movement. This indicates that the region had entered the period of the demise of the intracontinental depression. However, at this time, the Wuxia Fault Zone was more active in some areas in front of the Hala'alat Mountains. During the J1-J2 period, in the tectonic period of stabilization, the northwestern margin remained relatively stable in terms of subsidence except for part of the terrain on the side of the Hala'alat 
Mountains. Additionally, the Jurassic strata overlaid the stacked tile-like alluvial wedge formed in the Paleozoic, and the west-to-east extensional background of J3 occurred in the J3 period, when regional crustal movement in the Junggar Basin was followed by the reactivation of the secondary fracture tectonics in the northern rebound thrusting area. This movement caused different degrees of uplift, denudation, and stratigraphic loss in $\mathrm{J} 2$ and $\mathrm{J} 3$ as a result of the relift of other areas except the slope, especially the folded areas [11].

During the same period, against the background of intracontinental plate tectonics under compression, a lacustrine basin sedimentary system from river (delta) to lake was formed in the basin. The most remarkable feature is that the vertical rock type combination follows a rhythmic cycle of thinning and then thickening from bottom to top. The study area belongs to a series of pinch-out zones formed by overlaps, which belong to the hanging wall structural area of the secondary Xiahong North Fault of the Wuxia Fault structural belt. The tectonic area finally formed in the late Yanshan movement, which experienced the continuous transformation of the late Hercynian movement, including the Indosinian movement $[12,13]$.

The study area is located in the Wuerhe area of Fengcheng oil field in the Wuxia Fault Zone (Figure 2). Taking well W105 in the study area as the center, two sections from the northern boundary to the southern boundary and from the northwestern to the eastern boundary are selected. The east-west section includes six exploration wells in the Wuerhe area, including wells W293, W107, W28, W105, W112 and W104. The north-south section starts from well W42 at the high point of the slope and passes through four more exploration wells: W110, W105, W116 and FengN1.

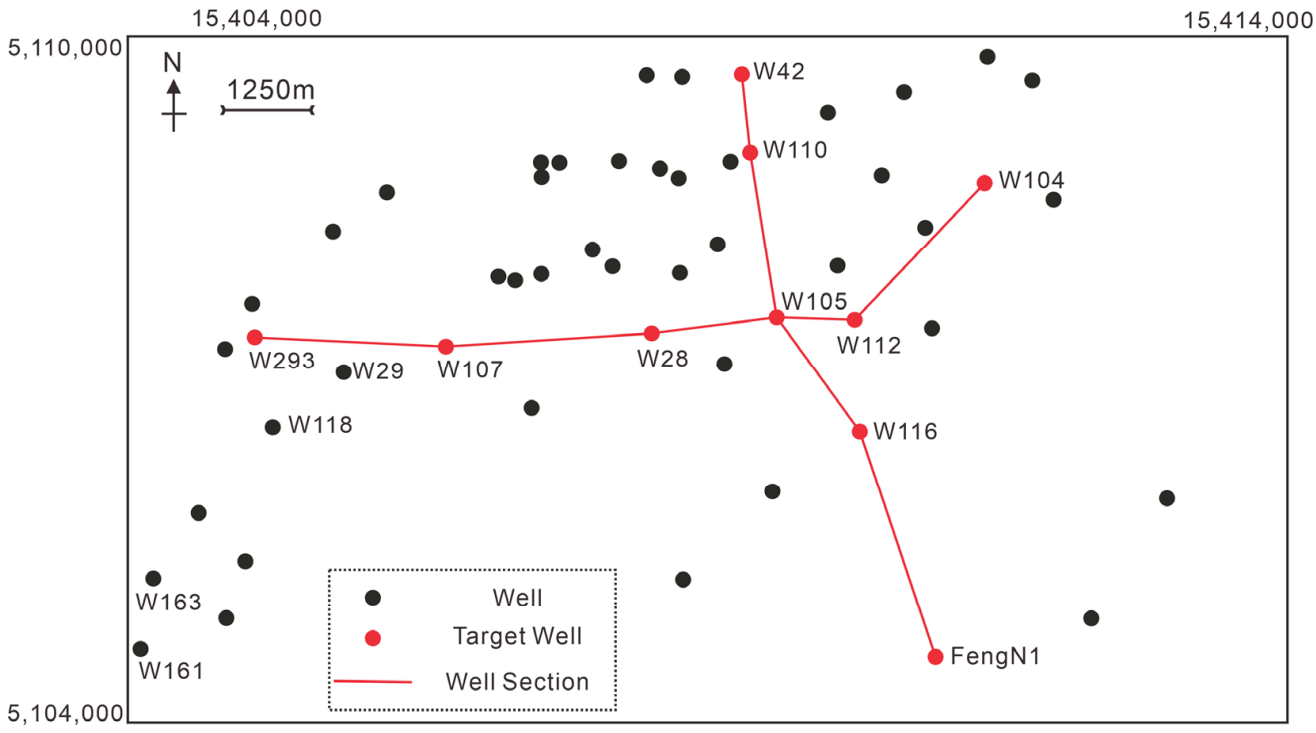

Figure 2. Location map of the W105 well area.

\section{Stratigraphic Classification and Correlation}

The study area is mainly located in the sloped portion of the basin, with material sources from the Hala'alat and Zaire Mountains. The stratigraphic thickness is larger than that of other ages, and typical Jurassic strata are developed [14,15].

In the study area, the specific stratigraphic development of each well varies. Among them, $\mathrm{J} 1 \mathrm{~b}$ is in angular unconformative contact with the underlying strata, and J3q is in angular unconformative contact with its upper Cretaceous strata.

The stratigraphic divisions and correlations in the study area come mainly from the stratigraphic calibration of the seismic profile, so the stratigraphic development in the study area is as follows. From west to the east on the east-west profile, as shown in Figures 3 and 4, the stratigraphic development tends to be complete, with well W293 located on the western boundary and well W104 on the eastern boundary of the well area. 


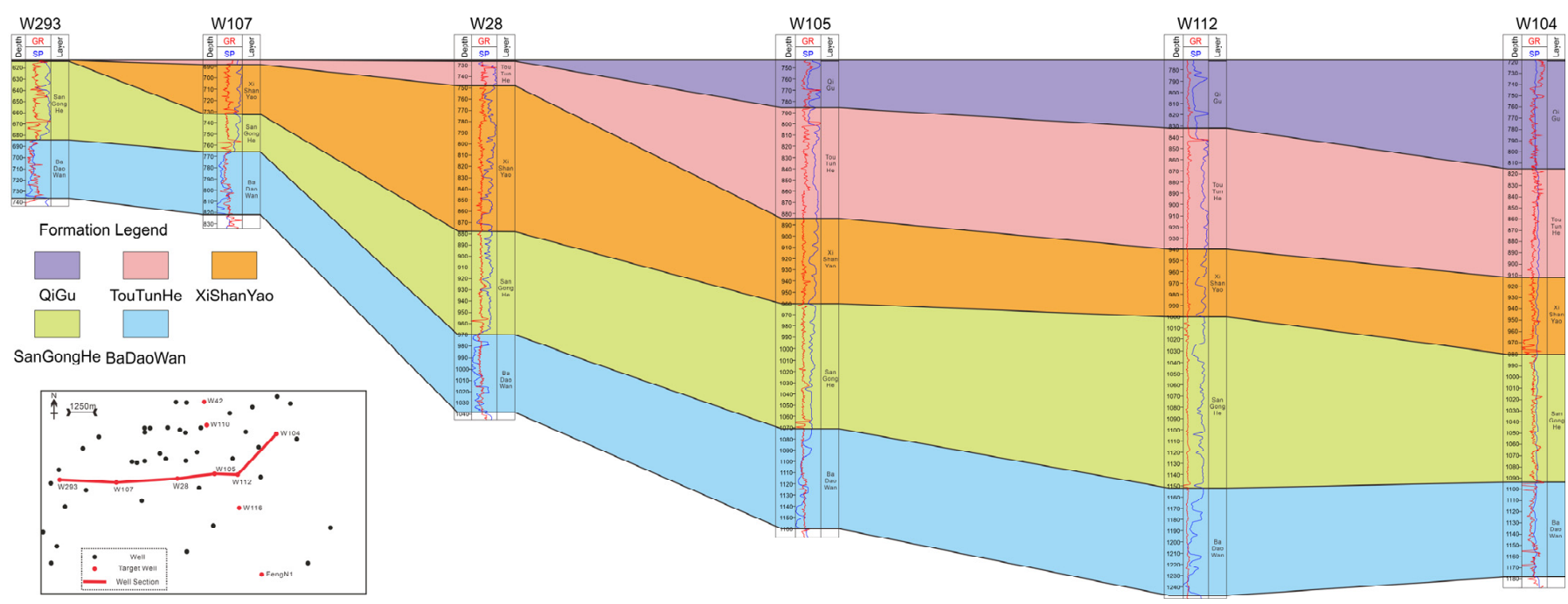

Figure 3. Stratigraphic correlation profile of the east-west section.

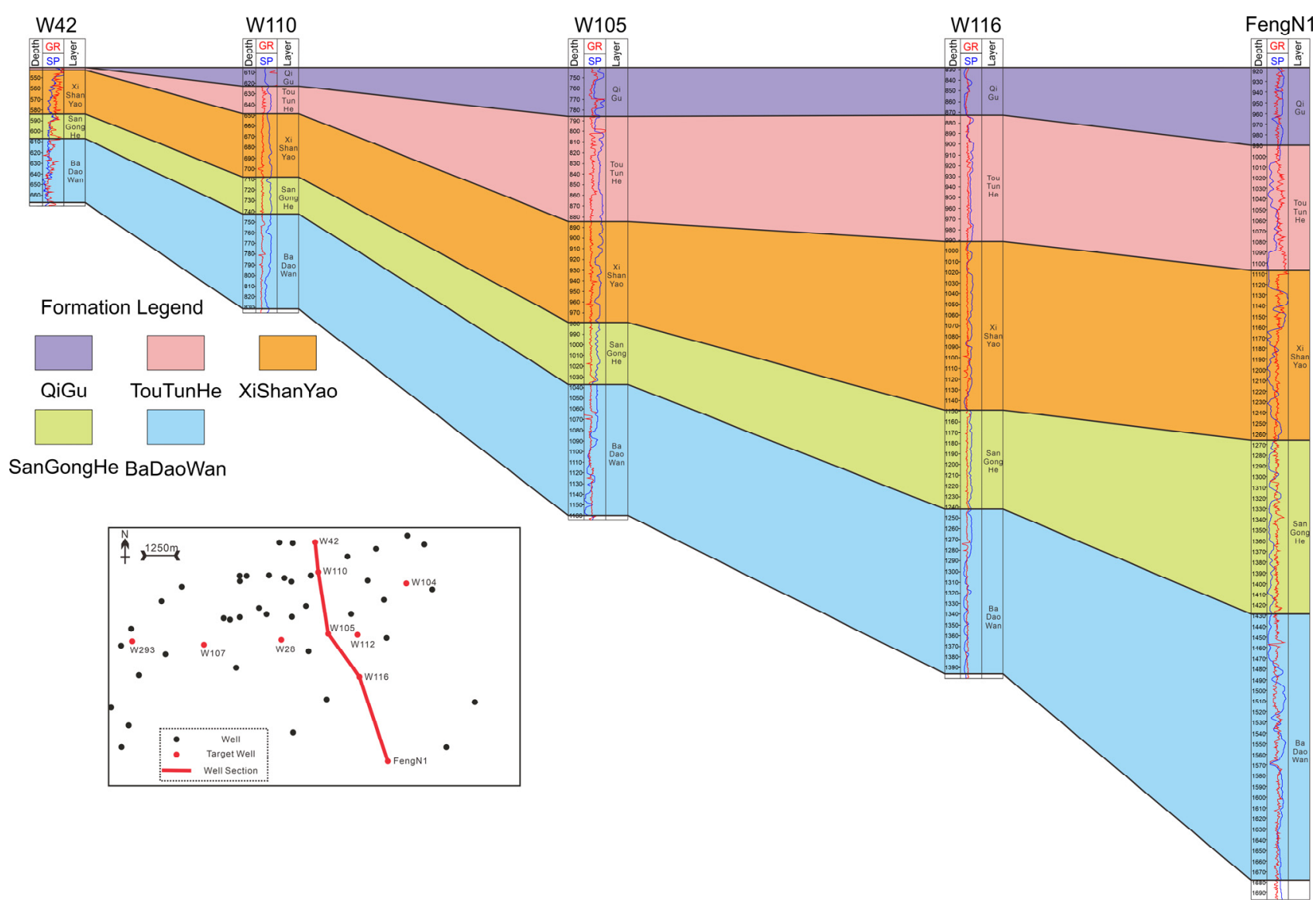

Figure 4. Stratigraphic correlation profile of north-south section.

The Badaowan Formation is very widely distributed in the study area, and it has a large stratigraphic thickness, ranging from 60 to $430 \mathrm{~m}$. Two sets of coal layers are developed, the lower portion of which is mainly sandy conglomerate or coarse sandstone containing gravel, and the upper portion is dominated by mixed-color mudstone with siltstone [16]. From bottom to top, three sets of sandstone layers with large thicknesses are mainly developed, which makes them clearly different from other strata [17]. 
The Sangonghe Formation is distributed across the study area and is thinly developed on the northwest side, with a thickness ranging from 20 to $280 \mathrm{~m}$. Mainly on the northwest side of the study area, it shows frequent interbedded gray mudstone with thin-bedded siltstone. In the southern portion of the study area, the lithology gradually changes to thicker layers of mudstone sandwiched by relatively coarse clastic rocks, including fine siltstone or sandy mudstone, and the color of upward mudstone becomes relatively lighter; e.g., yellowish brown.

The Xishanyao Formation formation thickens from the northwest side to the south of the study area, with exfoliative loss on the northwest side and the sedimentary center shifting to the south. The thickness is approximate 0 to $250 \mathrm{~m}$. The mudstone interbedded with siltstone develops at the bottom and gradually changes to siltstone interbedded with gravelly medium-fine sandstone or sand conglomerate upward. The top mudstone color changes, as reflected by a shift from dark colors such as gray and brownish gray to lighter colors that represent relatively oxidized environments, such as yellow (reddish) brown or red.

The Toutunhe Formatio is approximately 0 to $250 \mathrm{~m}$ thick. An absence due to stratigraphic erosion exists in the northern portion of the study area [18], when the northern crust was uplifted and the sedimentary center shifted significantly southward. The lithology of the lower part of this formation is mainly gray, gravelly, fine siltstone or gravelly, coarse sandstone with thin mudstone. At the top of this formation are gray medium-thick bedded sandstone conglomerates similar to the Qigu Formation [19].

The Qigu Formation is less developed in the study area, and its formation is thin with a thickness ranging from 9 to $220 \mathrm{~m}$. There are deficiencies in the western border and the northern border. The thickness is generally small and mainly includes thick-layered sandy conglomerates. The proportion of coarse clastic sediments increases and gradually thins from south to northwest, which is mainly the result of fan-delta sedimentation [20].

\section{Characteristics of Sedimentary Facies in the Study Area}

Sedimentary facies refers to the comprehensive performance of the sedimentary environment and sediments in the environment. Sedimentary subfacies are the secondary units of facies, and sedimentary microfacies are the secondary units of subfacies, the latter being sedimentary units formed under roughly the same sedimentary environment [20-23]. The study provides a basis for study and direct evidence of the spatial and temporal distribution and connectivity status of favorable sand reservoirs. It also provides a strong basis for the future exploration and development of an oil field and the recovery of the remaining oil [24-28].

We preliminarily analyze the sedimentary facies of a single well by using the morphological characteristics of the logging curve, including natural gamma (GR) and natural potential (SP) curves, supplemented by acoustic time difference curve (AC) and the $4 \mathrm{~m}$ bottom gradient resistivity curve (RT) $[29,30]$. The contact relationship, smoothness, amplitude and curve shape of each logging curve reflect the wellbore lithology and combination, the particle size change of sedimentary materials, each sedimentary cycle and contact relationship, water inflow and regression. At the same time, we can judge the sedimentary environment in combination with the lithology combination characteristics such as mudstone color to reflect the formation sedimentary facies [31]. For example, the box and bell curve combination can reflect channel sedimentation, and the sedimentary facies models of braided channels and distributary channels can be distinguished according to different combination forms [32].

Based on the previous studies, a detailed single-well logging facies division was constructed (Table 2) for 10 wells in the study area, using rock cuttings data, well logging data and regional seismic data [17-32]. There are five main well logging features. 
Table 2. Logging facies division.

\begin{tabular}{|c|c|c|c|c|c|c|c|c|c|}
\hline $\begin{array}{l}\text { Sedimentary } \\
\text { Facies }\end{array}$ & Subfacies & Microfacies & $\begin{array}{l}\text { Lithological } \\
\text { Characteristics }\end{array}$ & $\begin{array}{c}\text { Contact } \\
\text { Relationship }\end{array}$ & $\begin{array}{l}\text { SP Curve } \\
\text { Pattern }\end{array}$ & Range & Smoothness & $\begin{array}{c}\text { Environmental } \\
\text { Label }\end{array}$ & $\begin{array}{c}\text { Developmental } \\
\text { Level }\end{array}$ \\
\hline \multirow{2}{*}{ Fan delta } & \multirow{2}{*}{$\begin{array}{l}\text { Delta } \\
\text { Front }\end{array}$} & $\begin{array}{l}\text { Underwater } \\
\text { distributary } \\
\text { channel }\end{array}$ & $\begin{array}{l}\text { Sand and conglomerate } \\
\text { dominated, with } \\
\text { gravelly sandstone at } \\
\text { the bottom }\end{array}$ & Mutation & $\begin{array}{l}\text { Finger and } \\
\text { bell-shaped } \\
\text { compound }\end{array}$ & $\begin{array}{l}\text { Medium-high } \\
\text { range }\end{array}$ & Dentate & $\begin{array}{c}\text { Oxidative } \\
\text { environment }\end{array}$ & \multirow{2}{*}{$\begin{array}{l}\text { Badaowan } \\
\text { Formation }\end{array}$} \\
\hline & & Inter-channel & $\begin{array}{l}\text { Gray mudstone with } \\
\text { siltstone }\end{array}$ & $\begin{array}{l}\text { Gradual } \\
\text { change }\end{array}$ & $\begin{array}{l}\text { Micropatterned } \\
\text { linear }\end{array}$ & Low range & Micro-teeth & $\begin{array}{l}\text { Oxidative } \\
\text { environment }\end{array}$ & \\
\hline \multirow{3}{*}{ Lacustrine } & \multirow{2}{*}{$\begin{array}{l}\text { Shore-shallow } \\
\text { lacustrine }\end{array}$} & $\begin{array}{c}\text { Shore and } \\
\text { shallow } \\
\text { lacustrine mud }\end{array}$ & $\begin{array}{c}\text { Gray mudstone, } \\
\text { scattered within chalky } \\
\text { mudstone }\end{array}$ & $\begin{array}{l}\text { Gradual } \\
\text { change }\end{array}$ & Toothed linear & Low range & Dentate & $\begin{array}{c}\text { Oxidative } \\
\text { environment }\end{array}$ & \multirow{2}{*}{$\begin{array}{l}\text { Sangonghe } \\
\text { Formation }\end{array}$} \\
\hline & & $\begin{array}{l}\text { Lacustrine } \\
\text { marsh }\end{array}$ & $\begin{array}{c}\text { Thin black coal seam } \\
\text { scattered within gray } \\
\text { mudstone }\end{array}$ & Mutation & Fingerprint & $\begin{array}{l}\text { Medium-high } \\
\text { range }\end{array}$ & Smooth & $\begin{array}{l}\text { Restorative } \\
\text { environment }\end{array}$ & \\
\hline & $\begin{array}{l}\text { Semi-deep } \\
\text { lacustrine }\end{array}$ & $\begin{array}{l}\text { Semi-deep } \\
\text { lacustrine }\end{array}$ & Dark gray mudstone & Mutation & Toothed linear & $\begin{array}{l}\text { Medium-high } \\
\text { range }\end{array}$ & Smooth & $\begin{array}{l}\text { Restorative } \\
\text { environment }\end{array}$ & $\begin{array}{l}\text { Xishanyao } \\
\text { Formation }\end{array}$ \\
\hline \multirow{3}{*}{ Fan delta } & \multirow{3}{*}{$\begin{array}{l}\text { Delta } \\
\text { Plain }\end{array}$} & $\begin{array}{l}\text { (braided) } \\
\text { Distributary } \\
\text { channel }\end{array}$ & $\begin{array}{l}\text { Medium to fine } \\
\text { sandstone with gravel }\end{array}$ & Mutation & Bell-shaped & Medium width & Dentate & $\begin{array}{l}\text { Restorative } \\
\text { environment }\end{array}$ & Formation \\
\hline & & Estuary bar & $\begin{array}{l}\text { Muddy siltstone and } \\
\text { fine sandstone } \\
\text { dominate }\end{array}$ & Mutation & Box shape & $\begin{array}{l}\text { Medium-high } \\
\text { range }\end{array}$ & Micro-teeth & $\begin{array}{c}\text { Oxidative } \\
\text { environment }\end{array}$ & $\begin{array}{l}\text { Toutunhe } \\
\text { Formation }\end{array}$ \\
\hline & & Inter-channel & $\begin{array}{l}\text { Gray-brown and brown } \\
\text { sandy mudstone }\end{array}$ & $\begin{array}{l}\text { Gradual } \\
\text { change }\end{array}$ & Straight line & Low range & Micro-teeth & $\begin{array}{l}\text { Restorative } \\
\text { environment }\end{array}$ & Qigu Formation \\
\hline
\end{tabular}


1. Finger shape: The SP curve is a finger shape, mainly medium fine sandstone in lithology, with a thickness of less than $2 \mathrm{~m}$. Generally, the top and bottom interfaces of the finger curve are abrupt contacts, which can represent swamp and crevasse fan microfacies in general.

2. Straight line: When the SP curve is a straight line, generally the GR curve is relatively close to the mudstone baseline. At this time, it is the embodiment of fine-grained deposition under relatively quiet water conditions, and sometimes there is a teeth-shaped phenomenon. Generally, the linear shape is the reflection of argillaceous deposition under the condition of low water energy.

3. Bell shape: The corresponding rock shows a positive grain sequence vertically. When the spontaneous potential curve is bell-shaped, it usually indicates that the bottom is a scouring surface, which is in abrupt contact with the mudstone at the bottom and gradually changes at the top. Therefore, it reflects the gradual weakening of hydrodynamic conditions upward, which is a feature in various channel microfacies.

4. Funnel shape: A funnel shape mostly appears in combination with the box shape, showing a reverse grading cycle in the corresponding lithologic rhythm. The bottom of the sand body changes gradually, and the top is in abrupt contact with the mudstone. It is the log morphological interpretation of estuary bar microfacies.

5. Box shape: There are a smooth box shape, toothed shape and micro-teeth box shape according to the teeth state. The corresponding lithology is mainly gravelly medium-coarse sandstone, coarse sandstone, etc., which is usually a smooth box without fine-grained material, but the more serious the dentition, the more fine-grained the interlayer [29]. The abrupt contact with mudstone at the top-bottom interface is the response of the underwater distributary channel microfacies with a sufficient material source; more serious dentition represents the participation of an upward thinning positive cycle and more of a sand body interlayer, which is the reflection of the alternation of strong and weak hydrodynamic forces.

The sedimentary facies of the connecting well sections were further characterized in combination with the north-south section and the east-west section.

\subsection{Single-Well Logging Facies Study}

\subsubsection{Detailed Analysis of Well W293}

Well W293 is located in the westernmost portion of the east-west section of the well area, close to the western boundary. The stratigraphy is less developed, and the topographic position is higher. We divide the stratigraphy into two groups from bottom to top from the combined analysis of rock c logs and logging curves, as shown in Figure 5a.

The Badaowan Formation is divided into three sections from the bottom up, numbered 1, 2 and 3. Its total thickness is approximately $105 \mathrm{~m}$, and it is in angular unconformative contact with the underlying formation. The main lithology of the Badaowan Formation is generally gray conglomerate and coarse sandstone in the lower portion vs. gray siltstone, muddy siltstone and siltstone in the upper portion. In general, the grain size gradually becomes progressively finer upward, showing a positive grain order. Reflecting the gradual deepening of the water body, the thin black coal layer is a short-term indicator of the intersection of water and continent. The color of the rocks at the top of the three sections of Badaowan becomes brown. Sections 1 and 2 are dominated by sand and conglomerate, and the natural potential logging curve pattern is a high-amplitude jugged box shape with a wide variation in the bottom pattern. It belongs to the fan-delta plain subfacies and is specifically characterized by underwater distributary channel deposition [33]. The lower portion of the third section has a funnel-shaped morphology with low amplitude; it also belongs to the distributary channel microfacies. The upward thin coal layer indicates a floodplain swamp. Siltstone and sandy mudstone developed at the top combined with the dentate straight line of the SP curve and part of the finger-shaped middle amplitude. The top tapering morphology is judged as a muddy shallow lacustrine microfacies deposited by the shore-shallow lacustrine. 


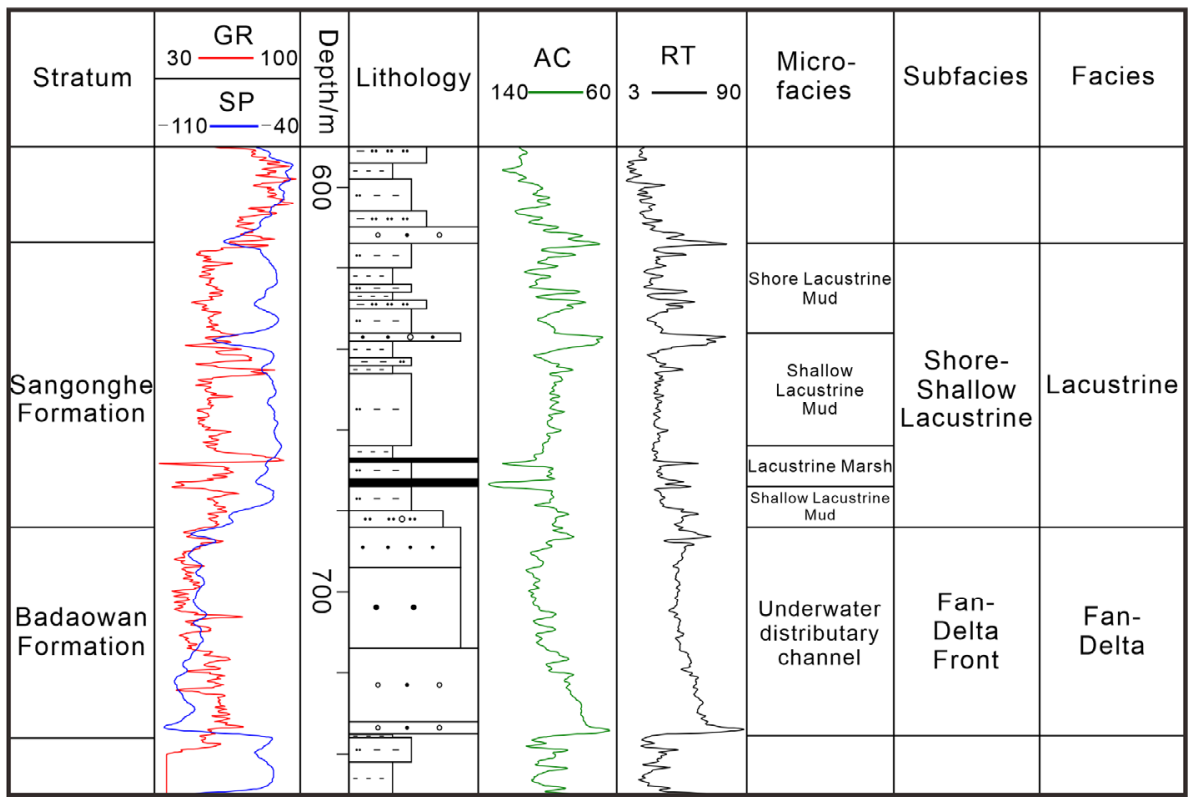

(a) Well W293

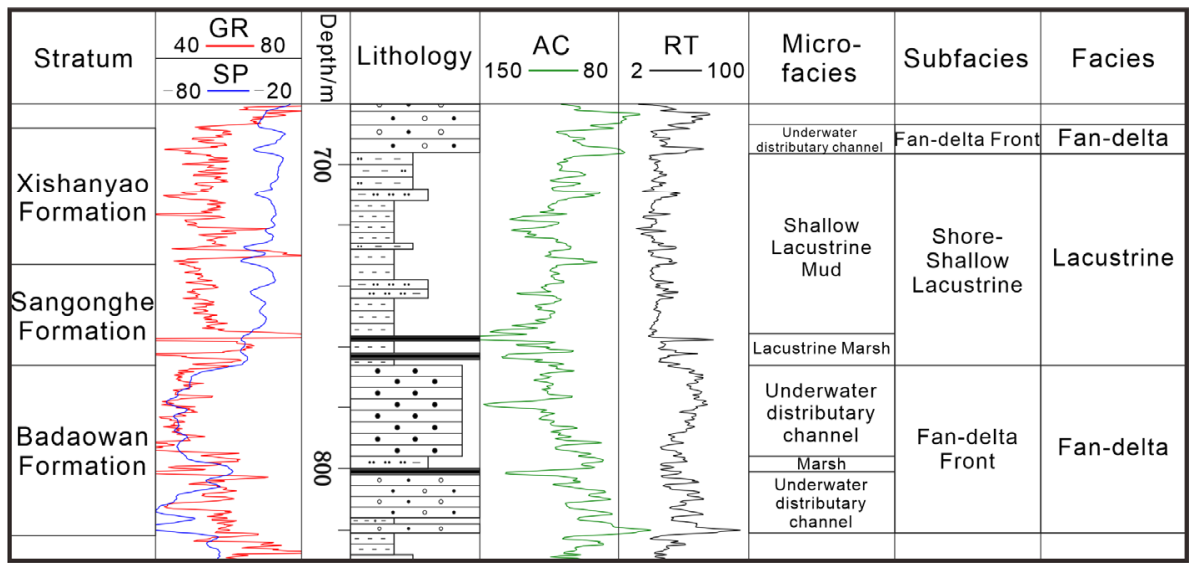

(b) Well W107

Figure 5. Single-well logging facies analysis of Well W293 and Well W107, (a) Well W293, (b) Well W107.

The Sangonghe Formation is relatively thin, at about $71 \mathrm{~m}$, and it is deposited continuously with the underlying Badaowan Formation. The lithology is mainly gray mudstone and slightly coarse-grained argillaceous siltstone. It is the main feature of argillaceous shallow lacustrine microfacies. This represents that the environment of the water body changes with energy weakening in the upward direction. It is in angular unconformative contact with the overlying Cretaceous strata, which is affected by sedimentary discontinuity and tectonic movement.

\subsubsection{Detailed Analysis of Well W107}

Well W107 is located in the east-west section of the study area. The stratigraphy is divided into three formations: the Badaowan Formation, Sangonghe Formation, and Xishanyao Formation, from bottom to top from the combination of rock cutting logs and logging curves, as shown in Figure 5b.

The Badaowan Formation is about $52 \mathrm{~m}$ thick. One section of Badaowan is gray sandstone and conglomerate; the logging curve is mainly a medium to high-amplitude jugged box shape. It represents the underwater distributary channel microfacies. The 
second and third sections of Badaowan are mainly gray and black mudstone with thin coal layers and gray coarse sandstone. The logging curve is a low-amplitude jugged bell shape, which represents the underwater distributary channel and marsh deposition at the front edge. The comprehensive analysis of the two thin coal layers at the top and the overlying Sangonghe Formation should be the lacustrine swamp microfacies entering the shore-shallow lacustrine sedimentation. The overall lithologic assemblage and rhythmic relationship with the Badaowan Formation of Well W293 are basically consistent.

The Sangonghe Formation is approximately $14 \mathrm{~m}$ thick. Its lithology is basically gray mudstone and siltstone. The bottom is a lacustrine marsh deposit, which changes upward into an argillaceous shallow lacustrine deposit dominated by gray mudstone.

The Xishanyao Formation shows continuous deposition with a thickness of $79 \mathrm{~m}$. Its lower portion is interbedded with mudstone and gray siltstone. The SP curve is a dentate linear and finger-like composite, representing muddy shallow lacustrine deposition; the upper portion is gray sand conglomerate of the medium to high-amplitude jugged box type, representing underwater distributary channel deposition. The Xishanyao Formation is in angular unconformative contact with the overlying formation.

\subsubsection{Detailed Analysis of Well W28}

Well W28 is located in the east-west section of the study area, and the stratigraphy is well developed. The stratigraphy is divided into five formations from bottom to top based on the combined analysis of rock cutting logs and well logging curves.

The Badaowan Formation is divided into three sections from the bottom up, numbered 1,2 and 3. The total thickness is approximately $85 \mathrm{~m}$, and it is angularly unconformative with the underlying formation. The main lithology is generally a set of gray sand conglomerates scattered within muddy siltstone and gray mudstone, while the upper portion is mainly a thin layer of fine conglomerate and gray mudstone. The overall grain size gradually becomes finer upward. The curve pattern in the lower portion is mainly a highamplitude jugged box type, representing braided distributary channel deposition. The SP curves in the upper portion are mostly dentate linear, with the grain size gradually becoming finer upward, representing inter-channel deposition, and the top coal layer is a floodplain swamp facies in an oxidized environment.

Regarding the Sangonghe Formation, with a total thickness of $86 \mathrm{~m}$, it is in integrated contact with the underlying Badaowan Formation. The lower portion is grayish-brown siltstone and mudstone, and the logging curve is a dentate straight line, representing the muddy shallow lacustrine microfacies deposited in the shallow lacustrine. Its upward gradation is interbedded gray muddy siltstone and mudstone, and the logging curve is a composite of finger-like and dentate straight lines, representing the sandy shallow lacustrine microfacies deposited in the shallow lacustrine.

The total thickness of the Xishanyao Formation is approximately $100 \mathrm{~m}$. The bottom is a small, shallow lacustrine sand bar deposit dominated by muddy sandstone; the portion above is a box-shaped medium to high-amplitude dentate muddy siltstone, representing sandy shallow lacustrine deposition; the upper portion is gray siltstone interbedded with gray mudstone with a fine grain size, representing muddy shallow lacustrine deposition. The upward mudstone color changes to yellowish brown, representing entering the plain environment. It is a plain inter-channel sediment. The top is gray pebbly sandstone, representing distributary channel deposition, which is in angular unconformative contact with the overlying Toutunhe Formation.

The Toutunhe Formation, is in integrated contact with the underlying Xishanyao Formation, with a thickness of approximately $10 \mathrm{~m}$. The lithology is mainly dentate bellshaped gray siltstone, representing a set of fine-grained material deposited inter-channel microfacies.

Regarding the Qigu Formation, the stratigraphic thickness is thin, at less than $20 \mathrm{~m}$, and it is in integrated contact with the underlying Middle Jurassic strata. The lithology is mainly brown mudstone representing the plain distributary channel and inter-channel 
deposits, and the upper portion shows a Cretaceous stratigraphy, with cutting and overlap in the high portion.

\subsubsection{Detailed Analysis of Well W105}

Well W105 is located at the intersection of the east-west and north-south sections of the study area. It is the central well location of the well area, and the formations are well developed. By the combined analysis of cutting logs and well logging curves, it can be divided into five formations from bottom to top (Figure 6).

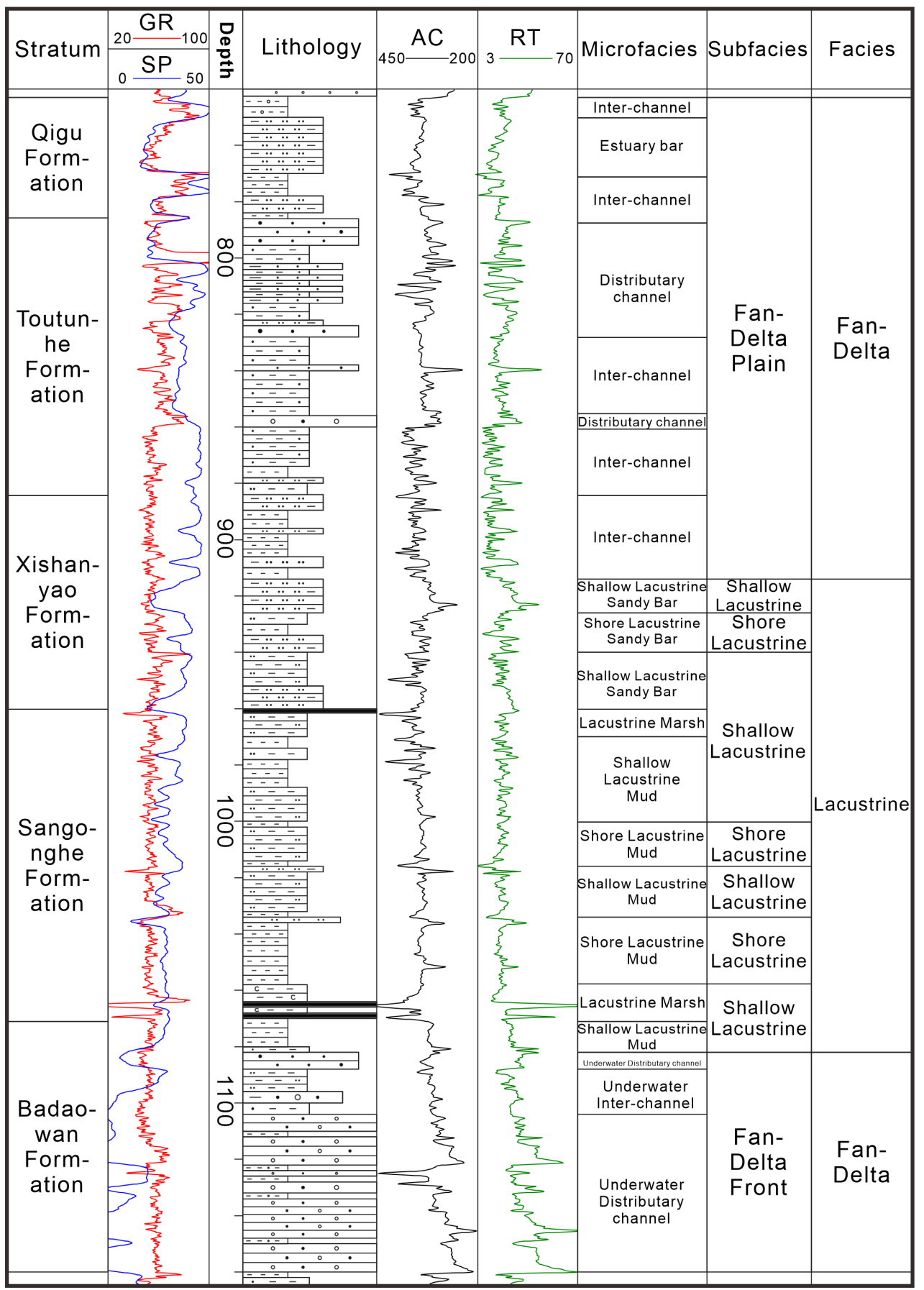

Figure 6. Single-well logging facies analysis of Well W105.

Regarding the Badaowan Formation, the total thickness is approximately $101 \mathrm{~m}$, with an angular unconformative contact between it and the underlying formation. The bottom 
lithology is mostly gray sandstone and conglomerate, and the upper portion is gravelly muddy fine sandstone with a medium-sized box and finger-shaped SP curve morphology, representing underwater distributary channel deposition at delta front subfacies. The top has a small bell-shaped and dentate linear morphology with a finer grain size, mainly as medium-fine sandstone and mudstone, representing the inter-channel deposition of a plain distributary channel. The coal layer above is deposited conformably with the Sangonghe Formation, and thin black coal and carbonaceous mudstone are products of lacustrine marsh deposition (Table 1).

Regarding the Sangonghe Formation, its total thickness is large, at about $112 \mathrm{~m}$. It is in integrated contact with the underlying Badaowan Formation. It is mainly composed of gray silty mudstone, siltstone and mudstone, which are frequently interbedded, with occasional thin brown mudstone layers. The mudstone is thick, and the overall shape of the logging curve is dentate and straight, with abrupt changes at the top and bottom. It represents the repetitive deposition of shallow lacustrine mud and shore lacustrine mud. The top is a thin coal layer, representing shallow lacustrine marsh deposition.

Xishanyao Formation: Its total thickness is approximately $94.5 \mathrm{~m}$. It is in integrated contact with the underlying formation. The lower portion is interbedded with brown siltstone and muddy siltstone, representing inter-channel and estuary bar microfacies. Occasional thin coalbeds in the lower portion are products of swamp deposition. The upper portion is interbedded grayish-brown muddy siltstone and brownish to yellowish-brown mudstone, which are deposited in an underwater distributary inter-channel. The SP curve pattern is low-amplitude bell-shaped and small finger-shaped, alternating with dentate straight lines.

The Toutunhe Formationis in integrated contact with the underlying Xishanyao Formation, with a thickness of $99 \mathrm{~m}$. Grayish-brown sandy mudstone and argillaceous fine sandstone are interbedded. The mudstone is thick and the sandstone is thin. Some brown sandy mudstone can be seen. The SP curve is a combination of dentate linear and box shapes, which is mainly the interaction of the plain distributary channel and interchannel microfacies formed by channel swing.

The total thickness of the Qigu Formation is approximately $45 \mathrm{~m}$. It is mainly gray muddy siltstone interbedded with gray or brown mudstone, and the two ends are mainly interfluvial deposits in a plain oxidized environment. The middle SP curve morphology is a medium amplitude micro-dentate box shape with tapering from top to bottom representing estuary bar deposition, which is consistent with the depositional characteristics of the Toutunhe Formation.

\subsubsection{Detailed Analysis of Well W112}

Well W112 is located in the east-west section of the study area, adjacent to wells W105 and W104. The formations are well developed and divided into five formations from bottom to top by the combined analysis of rock cutting logs and well logging curves (Figure 7).

Badaowan Formation: The total thickness of the stratum is approximately $96 \mathrm{~m}$. The main lithology is gray sandy conglomerate in the lower part; the SP morphology is box-shaped micro-dentate, which is deposited by the underwater distributary channel at the delta front subfacies. The upper portion contains brownish-gray siltstone and siltstone interbedded with bell-shaped and dentate linear combinations, representing the development of inter-channel microfacies; the lower portion is mainly fan-delta front subfacies. It gradually changes upward into dark-gray mudstone mixed with siltstone. It represents semi-deep lacustrine sedimentation. It is generally in a normal grading sequence.

Sangonghe Formation: Its overall thickness is approximately $152 \mathrm{~m}$. Its bottom is a set of lacustrine-facies swamps deposited by coal layers. Its upward lithology is mainly darkgray mudstone and muddy siltstone, frequently interbedded, which is the sedimentary feature of a large section of a semi-deep lacustrine. Thin layers of lacustrine swamp coal layer and gray mudstone are developed at the top. It represents lacustrine marsh and 
shallow lacustrine mud deposition. The Sangonghe Formation, as a whole, is a reserve grading sequence.

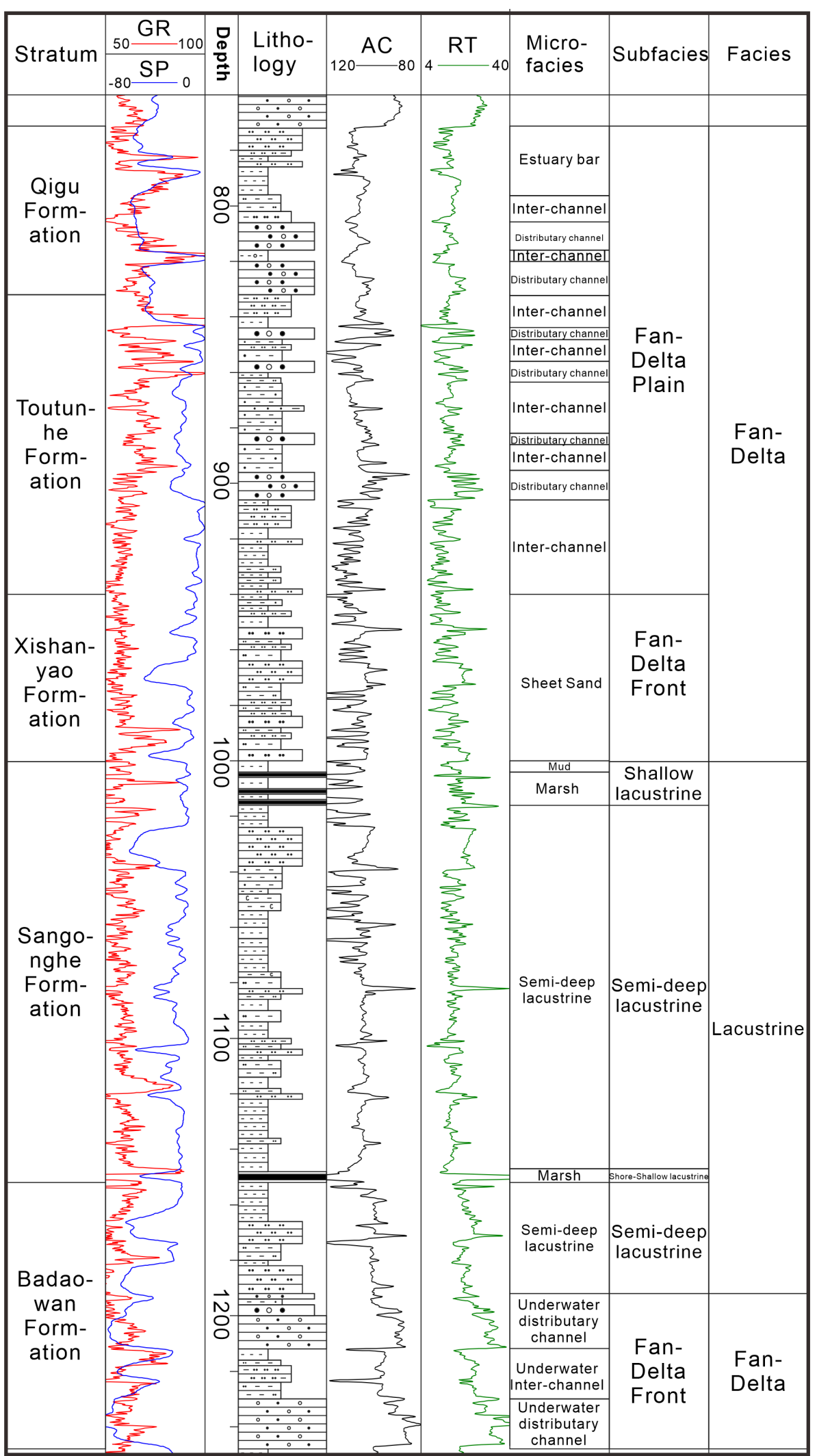

Figure 7. Single-well logging facies analysis of Well W112. 
Xishanyao Formation: This is a stratigraphically continuous deposition whose overall thickness is approximately $60 \mathrm{~m}$. As a whole, it is a medium dark-gray siltstone, with frequent interstratification of mudstone, and the SP morphology is a compound morphology of bell-shaped and finger-shaped, representing the deposition of delta front sheet sand.

The Toutunhe Formation is in integrated contact with the underlying Xishanyao Formation and has a thickness of $108 \mathrm{~m}$; the lower lithology is brown mudstone sandwiched by gray siltstone, and the grain size becomes coarser upward to medium-thick bedded gravelly, coarse sandstone. Combined with the shape of the SP curve, it is judged as representing plain inter-channel and distributary channel deposition. The thickness of the mudstone gradually decreases, and the thickness of the argillaceous siltstone increases.

The Qigu Formation is in integrated contact with the underlying Toutunhe Formation and has an overall thickness of $60 \mathrm{~m}$. The grain size of the rock gradually becomes finer upward. The light-gray, gravelly, coarse sandstone at the bottom represents distributary channel deposition in an oxidizing environment. The upward low-amplitude gray mudstone represents inter-channel deposition. The top portion is a combination of finger and bell-shaped estuary bar microfacies, depositing gray-brown muddy siltstone and gray siltstone.

\subsubsection{Detailed Analysis of Well W104}

Well W104 is located in the east-west section in the study area, close to the center of the work area and at the west side of the section. On the basis of cuttings logs and well logging curves, combined with seismic data, well W104 is divided into five formations.

Badaowan Formation: The thickness is approximately $80 \mathrm{~m}$. The bottom portion is an underwater distributary channel deposit at the fan-delta front, characterized by a box-shaped high-amplitude curvilinear morphology and gravelly, coarse sandstone. The lower portion is mainly composed of coal layers intercalated with fine sandstone, which is deposited by a lacustrine swamp and shallow lacustrine sand bar of a shore-shallow lacustrine. The upward transition is the delta front subfacies, and the lithology is mainly pebbly fine sandstone and sandy mudstone, representing the sedimentation of underwater distributary channels and inter-channels. Gray sandy mudstone and a thin coal layer is the main kind of sedimentation at the top, representing the occurrence of shore-shallow lacustrine marsh and shallow lacustrine mud deposition with a higher water level.

The San Gonghe Formation is approximately $114 \mathrm{~m}$ thick. The bottom is a thin coal layer with good continuity, representing lacustrine marsh deposition. The upper portion is sandy shallow lacustrine sedimentation with siltstone interbedded with sandy siltstone. Upward, it is primarily interbedded with mudstone and sandy mudstone, exhibiting a more argillaceous content, and mudstone mixed with argillaceous fine siltstone. The natural potential is a dentate straight line, which represents the argillaceous shallow lacustrine deposition of a shore-shallow lacustrine subfacies.

The Xishanyao Formation is approximately $70 \mathrm{~m}$ thick. The bottom is a thin coal layer deposited by a lacustrine marsh with good regional continuity. The lower portion is a sandy shallow lacustrine deposit characterized by gray muddy siltstone and shallow lacustrine mud deposited by gray mudstone, and the upper portion is dominated by fine sandstone, which is characteristic of underwater distributary channel deposition at fan-delta fronts. The presence of gray sandy mudstone at the top can be designated as the microfacies of underwater distributary inter-channel deposition.

The Toutunhe Formation is approximately $94 \mathrm{~m}$ thick. The lower portion is in unconformable contact with the interchannel of the Xishanyao Formation. The appearance of brown mudstone represents entry into the continental plain environment. Up-core is the plain distributary channel microfacies dominated by fine sandstone, and the presence of thick mudstone represents interchannel fine-grained deposition. Overlying this is the rock combination of interbedded fine sandstone and mudstone, which represents the multistage underwater distributary channel of continuous superimposed deposition. The sandstone and mudstone of inter-channel depositions are staggered. 
The Qigu Formation is approximately $96 \mathrm{~m}$ thick. Its lower portion is thick sandy conglomerate, representing underwater distributary channel deposition. Its upper portion appears to be interbedded with medium-fine sandstone and sandy mud layers, representing a distributary channel deposition environment. The upper brown mudstone represents the inter-channel environment.

\subsubsection{Detailed Analysis of Well W42}

Well W42 is located near the edge of the northern slope on the north-south section. Based on the rock cutting logs and well logging curves combined with seismic data, Well W42 is divided into three formations.

Badaowan Formation: With a total thickness of $14 \mathrm{~m}$, it is in angular unconformative contact with the underlying Triassic formation. It is mainly pebbly medium sandstone and fine sandstone deposited in front of an underwater distributary channel scattered within a fine-grained thin layer.

The Sangonghe Formation is approximately $50 \mathrm{~m}$ thick. The bottom is black-gray sandy conglomerate, representing limnetic deposits of shore-shallow lacustrine facies. Upward, it is gray sandy mudstone, representing argillaceous shallow lacustrine deposition. Further upward, the color of mudstone becomes lighter, and the sand content increases, representing the sedimentary characteristics of sand flats of shallow lacustrine facies. Lithologically, it is mainly represented by the interbedding of red mudstone and gray pebbly medium-fine sandstone, which gradually changes upward to pebbly argillaceous siltstone. This formation is mainly an alternation between mud flats and sandy shallow lacustrine.

Xishanyao Formation: Deposited conformably with the underlying formation, with a total thickness of $42 \mathrm{~m}$, it has a base of gravelly fine sandstone and light-gray quartz sandstone, representing the deposition of delta plain underwater distributary channels. The lithology changes upward to light-gray siltstone and muddy siltstone scattered within thin layers of red mudstone, which is the characteristic rock type of inter-channel deposition. The upward antigranular sequence represents the microfacies of estuarine bar deposition.

\subsubsection{Detailed Analysis of Well W110}

Well W110 is located on the north-south section near the center of the well area, and the formation is well developed. Well W110 is divided into five formations based on cutting logs, logging curves, and seismic data.

The Badaowan Formation is divided into three sub-formations from the bottom up, numbered 1, 2 and 3. The total thickness is approximately $89 \mathrm{~m}$. Its lithology is mostly gray, fluorescent, gravel-bearing medium sandstone, fluorescent siltstone scattered within siltstone mudstone and thin coal layers. The SP curve morphology is mainly dentate boxshaped and small amplitude bell-shaped, representing the depositional pattern between underwater distributary channels and inter-channels at fan-delta front.

Sangonghe Formation: The total thickness is $35 \mathrm{~m}$, with integrated contact with the underlying Badaowan Formation. It is primarily gray-brown mudstone, siltstone, and muddy siltstone. The formation deposition is mainly reverse grading with upward coarsening. A high proportion is mudstone, and the bottom is indicative of a lacustrine swamp, which is generally characterized by sandy shallow lacustrine microfacies of shoreshallow lacustrine deposition. Argillaceous shallow lacustrine deposits appear in the upper portion.

The Xishanyao Formation was deposited conformably with the underlying formation, with a thickness of approximately $59 \mathrm{~m}$, and the sedimentary facies is mainly delta plain. The lower rock type is primarily a brown muddy siltstone and reddish-brown mudstone, representing the inter-channel depositional microfacies. The grain size gradually becomes coarser upward for the medium sandstone deposited by the distributary channels, and the muddy siltstone deposited by the funnel-shaped estuary bar appears at the top. 
Toutunhe Formation: The total thickness is approximately $26 \mathrm{~m}$. Mainly interbedded gray muddy siltstone and mudstone, generally showing a reverse grading with upward coarsening. It is an inter-channel deposition of delta plain subfacies.

Qigu Formation: The stratigraphic thickness is approximately $19 \mathrm{~m}$, and it is in integrated contact with the underlying Middle Jurassic formation. The lithology is relatively homogeneous, gray sandy conglomerate, and the SP curve is a medium amplitude microdentate box shape, representing the braided distributary channels sedimentary microfacies. It is abruptly altered at the top and is in unconformative contact with the overlying strata.

\subsubsection{Detailed Analysis of Well W116}

Well W116 is located in the southern portion of the north-south section, adjacent to Wells W105 and FengN1. The formations are well developed, and the logging-based sedimentary facies mainly develop as the following sequence: fan-delta front, shoreshallow lacustrine, fan-delta front and fan-delta plain.

Badaowan Formation: The thickness is approximately $156 \mathrm{~m}$. The lower portion is mainly sandy conglomerate with a box-shaped SP curve, which is the product of underwater distributary channel deposition at the fan-delta front. Fine-grained material is deposited between distributary channels, the overall upward grain size becomes coarser, and gray thick-layered mudstone appears at the top, representing shore-shallow lacustrine deposition. In general, the Badaowan Formation was primarily deposited by continuously superimposed underwater distributary channel and inter-channels.

Sangonghe Formation: The thickness is approximately $92 \mathrm{~m}$. The bottom is lacustrine sediment; the lower is muddy shallow lacustrine sediment; the sandy shallow lacustrine sediment dominated by siltstone appears upward, and the top portion is lacustrine marsh sediment formed by three coal layers.

Xishanyao Formation: The thickness is approximately $156 \mathrm{~m}$. The microfacies changes little, and the bottom is a shallow lacustrine sand bar of shore-shallow lacustrine sedimentation, which enters the fan-delta front sedimentation while moving upward. It is mainly reflected in the interbedding of thick, silty mudstone and argillaceous siltstone. According to the characteristics of the SP curve shape, it is mainly divided with a sequence of fan-delta front inter-channels, sheet sand, inter-channels and underwater distributary channel logging facies combination.

Toutunhe Formation: The thickness is approximately $130 \mathrm{~m}$. The lithology is mainly the interbedding of thick, sandy conglomerate, fine sandstone and thin brown mudstone, reflecting the sedimentary characteristics of the fluctuating plain distributary channel and inter-channels combination.

Qigu Formation: The thickness is approximately $40 \mathrm{~m}$. Its SP curve is a box-shaped, high-amplitude feature, mainly for underwater distributary channel deposition. The top is gray siltstone and brown mudstone, representing inter-channel deposition.

\subsubsection{Detailed Analysis of Well FengN1}

The FengN1 well is located in the thicker area of the southern slope stratigraphy of the north-south section, close to the hinterland of the basin. The overall development of formations is relatively more complete. On the basis of cuttings logs and logging curves, combined with seismic data, well FengN1 is divided into five formations.

Badaowan Formation: It is thick, with a total thickness of approximately $200 \mathrm{~m}$. The lithology is mainly thick layers of greenish-gray sandstone and grayish-white, poorly sorted conglomerate sandstone, changing to grayish-white sandstone while moving upward, representing the interactive deposition of the underwater distributary channel and inter-channels at the fan-delta front. The top portion is a greenish-gray mudstone layer, representing the deposition of shallow lacustrine mudstone.

Sangonghe Formation: It is even thicker than the Badaowan, at $175 \mathrm{~m}$. A $10 \mathrm{~m}$ thick coal layer is at the bottom. It is highly continuous and widely distributed in the region, representing the lacustrine deposits of the shore-shallow lacustrine. The upward lithologic 
variety is relatively homogeneous, mainly giant, thick, greenish-gray mudstone and sandy mudstone, representing relatively stable muddy shallow lacustrine deposition. The black coal layer appears at the top, representing lacustrine marsh deposition.

Xishanyao Formation: The total thickness is approximately $175 \mathrm{~m}$. The bottom portion is a single-layer shore-shallow lacustrine argillaceous deposit, which enters the fan-delta front deposit while moving upward, and the lower portion is greenish-gray mudstone mixed with variegated fine conglomerate, representing the underwater distributary channel and inter-channel deposition of the front portion. The upper portion is greenish-gray argillaceous sandstone intercalated with variegated fine conglomerate, which is the underwater distributary channel environment of the fan-delta front. The top portion is greenish-gray thick argillaceous sandstone, which belongs to the underwater distributary channel deposition.

Toutunhe Formation: It makes angularly unconformative contact with the underlying Xishanyao Formation, with a thickness of $135 \mathrm{~m}$. The bottom is thickly bedded dark-gray mudstone, representing semi-deep lacustrine deposition. The greenish-gray, thick-layered muddy sandstone that appears upward from the shallow lacustrine deposits is the product of shallow lacustrine sand bar deposits. It contains $20 \mathrm{~m}$ thick shallow lacustrine mud deposits. Its SP curve is a dentate box shape.

Qigu Formation: The total thickness is approximately $72 \mathrm{~m}$. Its coarse grain size and the red color of mudstone indicate a fan-delta plain oxidized environment. It is mainly graywhite medium sandstone deposited by distributary channels and red mudstone deposited inter-channels.

\subsection{Sedimentary Facies Analysis of Connecting Well Profiles}

Taking Well W105 in the study area as the center, two sections from the north boundary to the south boundary and from the northwest to the east boundary are selected. The eastwest section consists of six wells in the Wuerhe area and the north-south section consists of five wells.

The north-south section starts from well W42 at the high point of the slope and passes through several wells to cut into the basin where the basin slope is the thickest.

\subsubsection{East-West Section}

The section is located in the north of the center of the study area, in the direction of northwest to northeast (Figure 8). Well W293 is close to the western boundary of the study area, while Well W104 is close to the center of the study area. Therefore, the east-west sedimentary facies profile from Well W293 to Well W104 can provide a certain basis for the vertical distribution and horizontal prediction of sedimentary facies from the boundary to the center.

In this sedimentary facies diagram of an connecting well profile, the sedimentary facies of the Badaowan Formation is mainly the fan-delta front, with good continuity of the underwater distributary channels deposits, and the sand body is mainly dominated by channel sand. The bottom of the Sangonghe Formation distributes continuously deposited lacustrine swamps, which represent the groundwater diving surface flush with the lacustrine level, and the lacustrine level is approximately $1 \mathrm{~m}$ to $5 \mathrm{~m}$. A wetland swamp is formed when the water level rises, and in the process of changing the water level, the organic matter is in a humid anaerobic underwater environment, which cannot be exposed to enough oxygen and is not easily decomposed by aerobic bacteria. Therefore, it cannot be completely decomposed to form carbon-rich layers or coal layers. The Sangonghe Formation is mainly composed of shallow-shore lacustrine deposits of lacustrine facies. Specifically, mudstone accounts for more than $50 \%$, which is argillaceous shallow lacustrine deposits with more sand content, and its mudstone is sandy shallow lacustrine deposits. From the west side to the east side of the profile, the lacustrine depth increases, and semi-deep lacustrine deposits formed by dark-gray mudstone appear near Well W112, with a small distribution range. It can be used as a good source rock. On the profile from Well W105 to Well W104, 
several thin coal layers are developed at the top of the Sangonghe Formation, representing the sedimentary environment of a transient water-land interaction from shore-shallow lacustrine deposition to continental fan-delta front deposition. Fan-delta front deposits are not developed at the western boundary of the study area. Fan-delta plain deposits are developed from the Xishanyao Formation to the Toutunhe Formation in the section from Well W107 to the middle of the study area. Near Well W105 to the east of the profile, i.e., the center of the study area, fan-delta plain deposits with nearly equal thickness are developed.

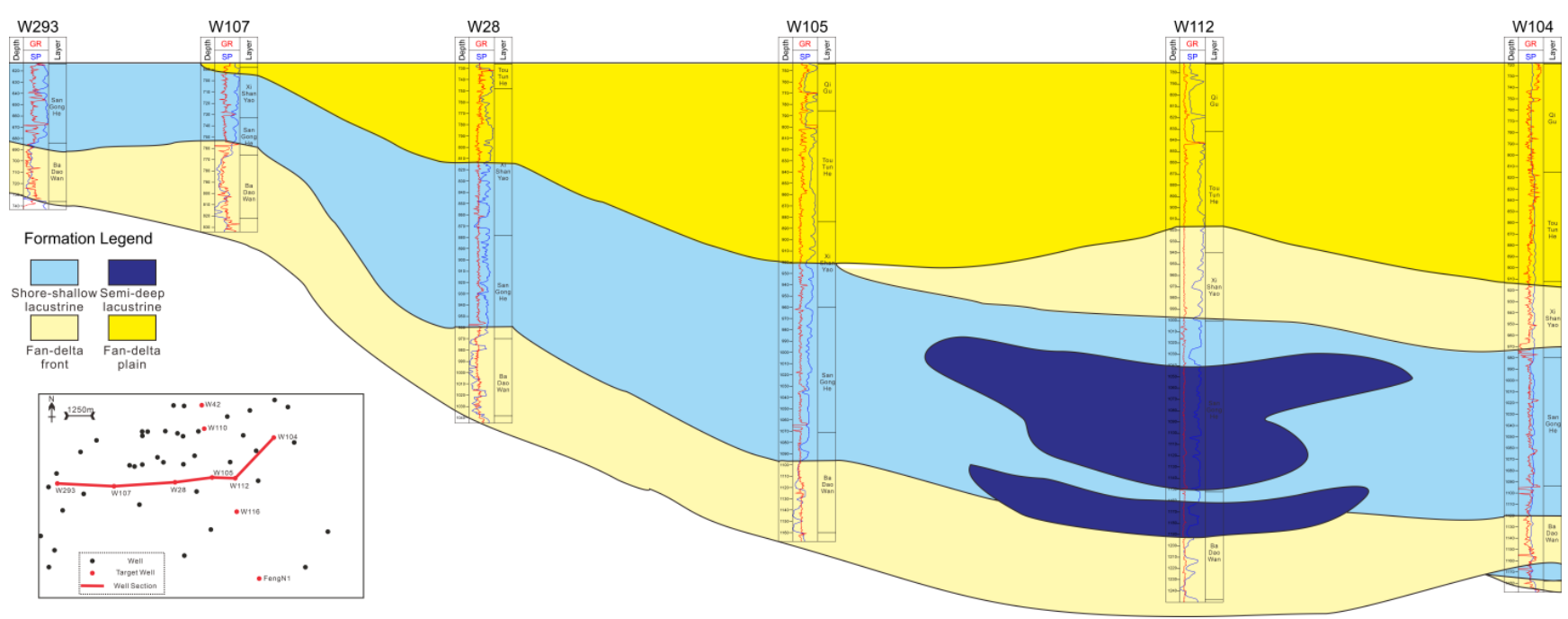

Figure 8. Sedimentary facies diagram of an east-west connecting well.

\subsubsection{North-South Section}

The section is located in the east of the central portion of the study area in a nearly north-south direction (Figure 9). The profile is selected from Well W42 at the thin formation of the basin slope, along the trend of the basin slope to Well FengN1, close to the hinterland of the basin. There are five exploration wells, covering most of the north slope of the small basin. They provide an intuitive understanding of the change in formation thickness and the vertical sequence and distribution of sedimentary facies from the high end of the slope to the basin.

Well W42 is located near the northern boundary of the study area, and the sedimentary stratigraphy of Well W42 includes the Badaowan, Sangonghe and Xishanyao Formations, while the overlying Toutunhe and Qigu Formations are missing due to denudation by tectonic movements. From the analysis of the sedimentary facies of this well, the fandelta facies is mainly dominant. The dominant facies is the fan-delta plain and fan-delta front; and some are shore-shallow lacustrine. The sand deposits are primarily braided distributary channels, an underwater distributary channel, and far sand bars. Well FengN1 is close to the southern boundary of the study area, where the stratigraphic development is complete and thick. The shore-shallow lacustrine deposits are thicker than the northern boundary. Semi-deep lacustrine sedimentation with small thickness is developed in the Toutunhe Formation, and two sets of sedimentary cycles are developed from bottom to top.

From the northern boundary of the study area to the southern boundary, i.e., the bottom of the slope, the stratigraphic development tends to be complete, and the stratigraphy is clearly thickening. The J1b sedimentary facies is primarily fan-delta front. While moving upward, J1s is mainly a shore-shallow lacustrine sedimentary environment, and semi-deep lacustrine sedimentation can be seen in the east-west section. Starting from the Sangonghe Formation, it enters a new depositional cycle; that is, the depositional system of the anti-rhythmic cycle of the shore-shallow lacustrine, fan-delta front and fan-delta plain, vertically. The laterally connected sets of sand bodies formed by the distributary channel deposited in the plain have a wide range of sand body distributions, and the thickness of the sand body in the south is larger than that in the north. Additionally, multiple sets of 
channel sand are also developed. Similarly, the sand bodies of underwater distributary channels and estuary bars in the front have high longitudinal thickness in the south and less to the north, and the sand bodies of the Badaowan Formation have high continuity. The thicknesses of sand bodies deposited in front of the Xishanyao Formation and Toutunhe Formation are thin, and their continuity is poor.

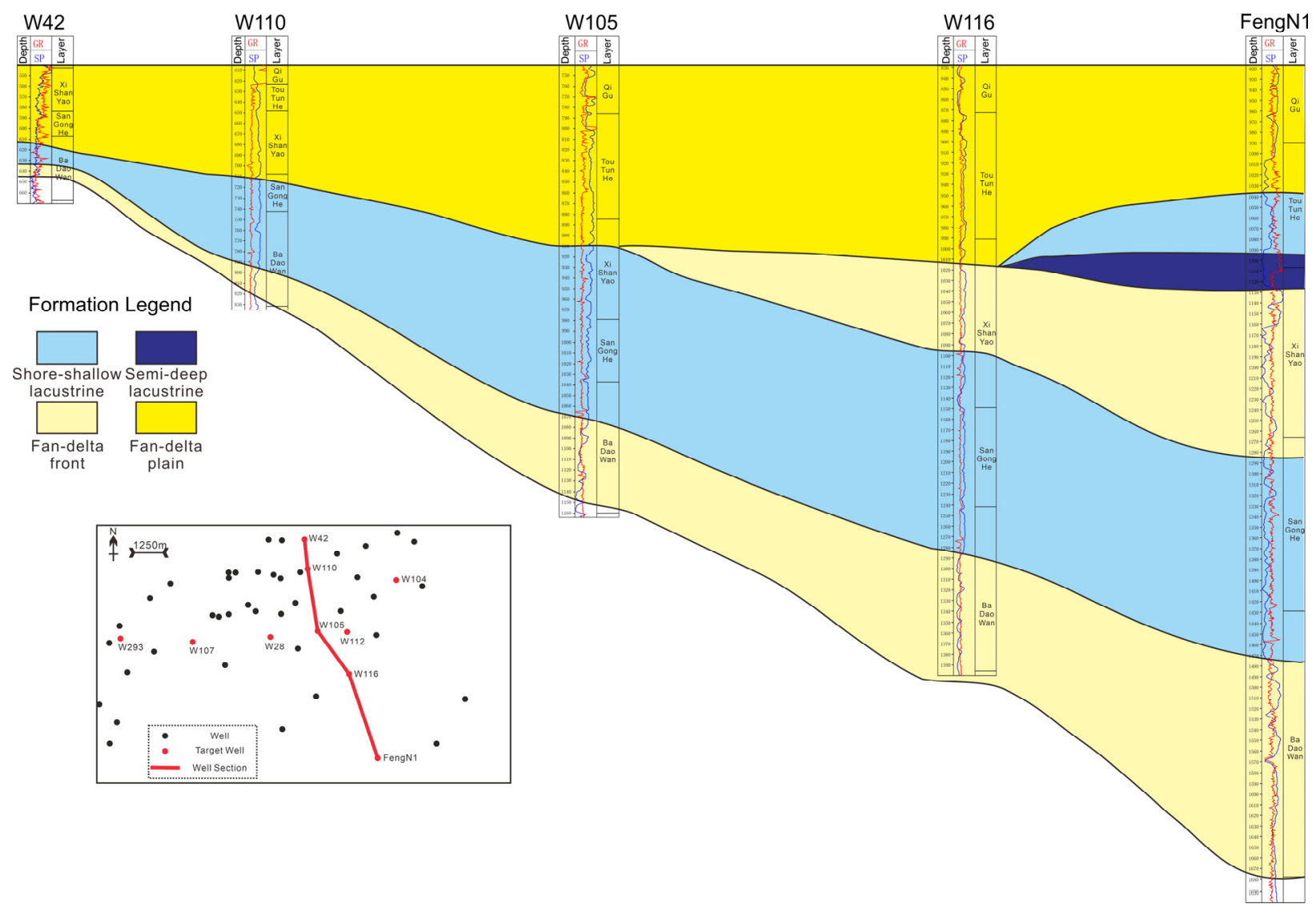

Figure 9. Sedimentary facies diagram of a north-south connecting well.

\section{Analysis of the Sedimentary Facies and Sedimentary Evolution in the Study Area}

In the process of analyzing the overall Jurassic depositional environment in the study area and the different sedimentary evolution in each period, the sandstone thickness contour map and the net to gross ratio planar view map can well reflect the depositional processes and changes in the study area during each depositional period. However, in the process of using the sandstone thickness planar view map and the net to gross ratio contour map, the influence of objective factors such as the thickness of the stratum itself on the interpretation of the map should be taken into consideration.

Previous study suggests that the Jurassic sedimentary facies in the study area mainly includes braided fluvial facies, braided fluvial deltas and lacustrine facies [5-7]. However, in the prediction of sedimentary facies of the Sangonghe Formation of the Upper Jurassic, there have always been some disputes about whether they are shallow lacustrine facies, braided fluvial facies or (fan) delta facies [5-7]. On the other hand, taking the Qigu Formation as an example, some studies have stated that the sedimentary facies was braided fluvial depositions [8], with microfacies such as channels, central bars, floodplains and natural levees. In contrast, through the net to gross ration distribution and the sedimentary facies of every wells, we believe that the Qigu Formation is a fan-delta plain facies.

A larger net to gross ratio indicates a greater thickness of sandstone for the same stratigraphic thickness. In addition, the direction in which the net to gross ratio decreases is the advancing direction of the river or distributary channel. In the delta deposition system, 
the sandstone content decreases and the mudstone content increases from the delta plain to the delta front. Therefore, in the complete fan-delta longitudinal sedimentary system of continuous deposition, the lithology gradually changes from mudstone-dominated to sandstone/sand conglomerate-dominated from the deltaic mud to the sheet sand, underwater distributary channels, braided distributary channels, and far estuary bar, and the grain size coarsens in the upward direction. These make up a complete delta deposition system. Theoretically, the complete delta deposition system has a set of upward coarsening antiarrhythmic cyclones. In addition, the area with a large net to gross ratio may be the source direction of the material, and the analysis would be more comprehensive when combined with heavy minerals and other data. The net to gross ratio contour map can also reflect the change in water depth, the energy strength, and the dominant facies in the sedimentary facies.

Within the constraints of the net to gross ratio, sedimentary microfacies can be analyzed in conjunction with cores, outcrops and logging and seismic data, and the distribution boundaries of sedimentary subfacies can be controlled.

By measuring the stratigraphic thickness, sand thickness and net to gross ratio of each Jurassic formation in the Fengcheng-Wuerhe area, the sand thickness contour map and then the net to gross ratio contour map of each formation were drawn. The sedimentary facies planar distribution map was drawn by using the sand thickness and net to gross ratio contour map of each formation (Figures 8 and 9). By studying the sedimentary facies distribution maps of each formation, we can reveal the change of depositional patterns of the studied Jurassic formation during the depositional period.

\subsection{Badaowan Formation}

According to the net to gross ratio of the Badaowan Formation, the overall sandstone thickness in the study area is relatively thicker. Combined with the logging curves, lithology columns and seismic profiles, it can be found that the stratigraphic thickness of the Badaowan Formation is varying, ranging from the absence of this section of some wells to a maximum thickness of $190 \mathrm{~m}$. On average, the overall thickness is approximately 40-80 m. According to the net to gross ratio contour (Figure 10a), the material source of the Badaowan Formation comes from one direction: northwest. Combining the seismic profile and logging facies, the study area is mainly large-scale fan-delta front from northwest to southeast, depositing a large set of medium-thick sandy conglomerates or pebbly sandstones. Longitudinally, the particle size of the upper section of the Badaowan Formation becomes finer, and the lithology gradually changes to fine siltstone with a coal seam. It represents floodplain and swamp deposits under humid conditions.

The sand body in the study area is concentrated in the underwater distributary channel at fan-delta front facies. The main channel is developed from the northwest to southeast direction of the study area, and branch channels are developed near Wells W104 and W293. According to the sedimentary facies planar view, the fan-delta front sedimentary system is primarily developed in the study area. The lacustrine facies are distributed in a small range in the southwest and northeast, and the fan-delta plain is basically not developed (Figure 11a). 


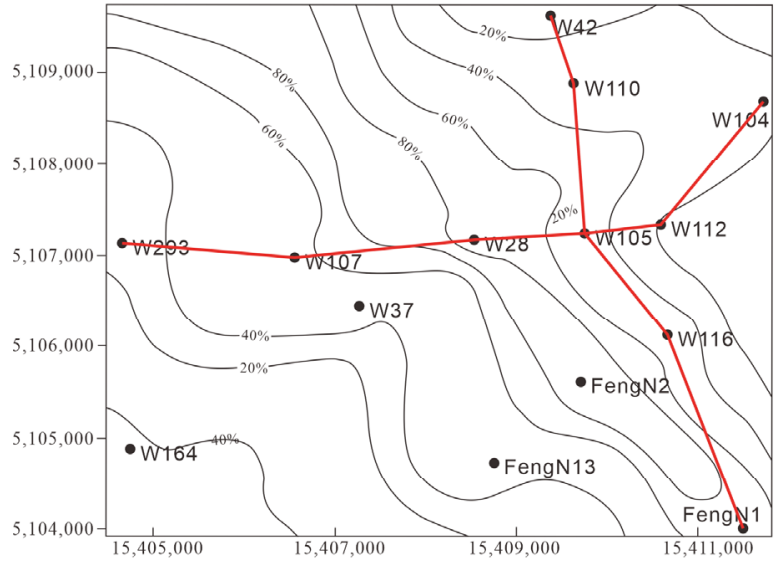

(a)

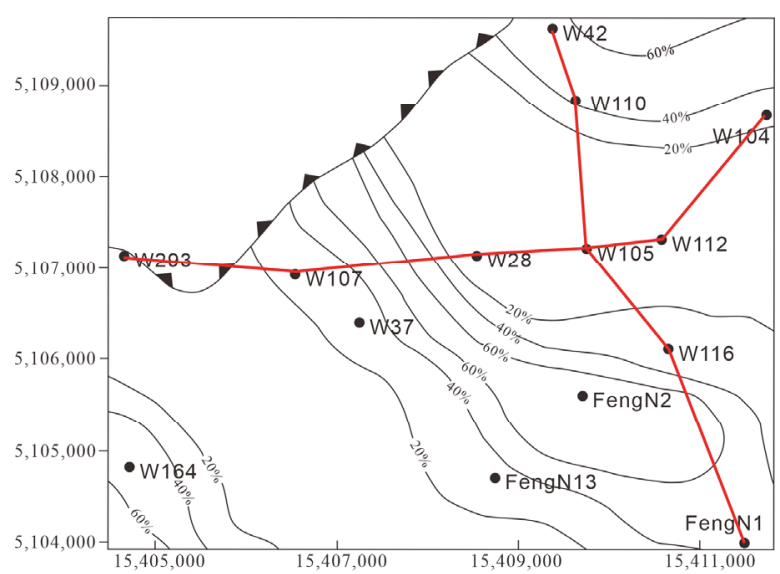

(c)

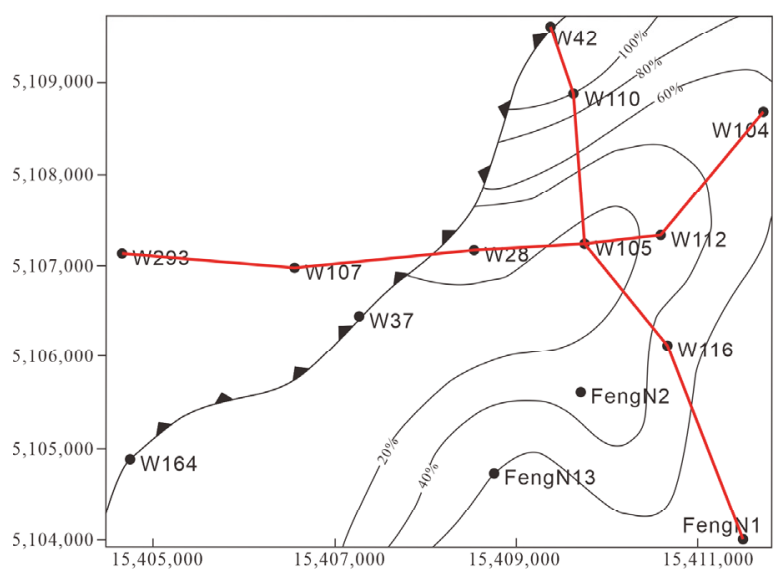

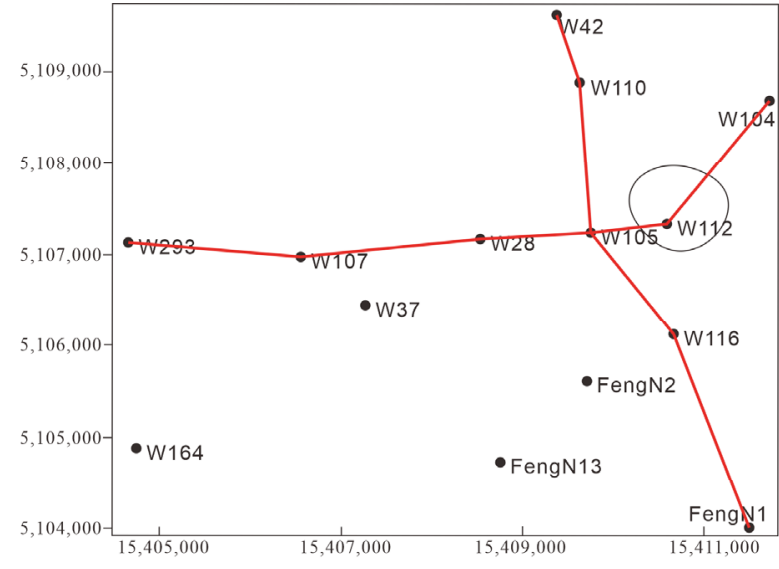

(b)

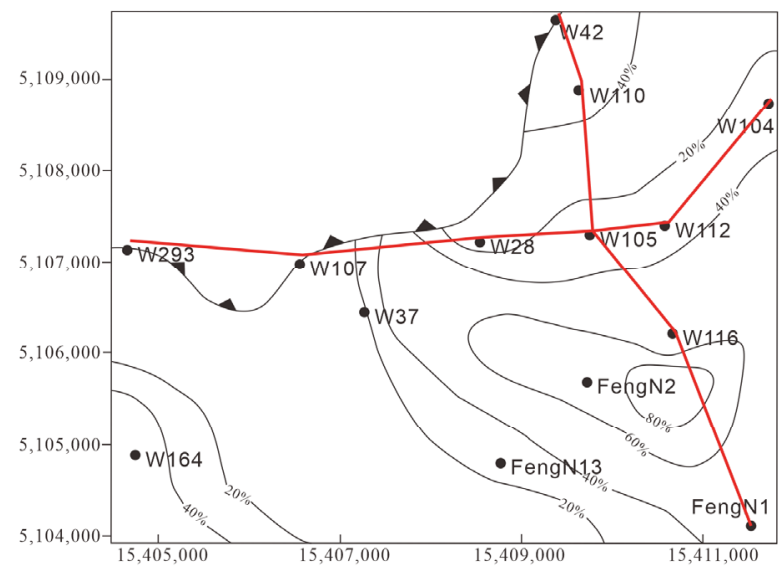

(d)

\section{Legend}

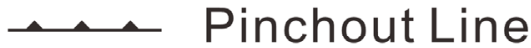

$-20 \%$ - Net to gross ratio contour

Well Section

\section{W105 Well}

(e)

Figure 10. Contour map of the net to gross ratio of Jurassic strata in the study area: (a) Badaowan Formation; (b) Sangonghe Formation; (c) Xishanyao Formation; (d) Toutunhe Formation; (e) Qigu Formation. 


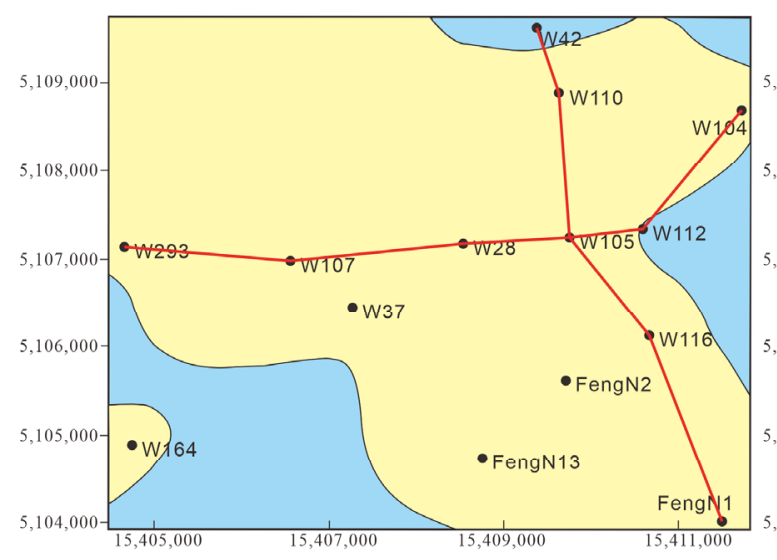

(a)

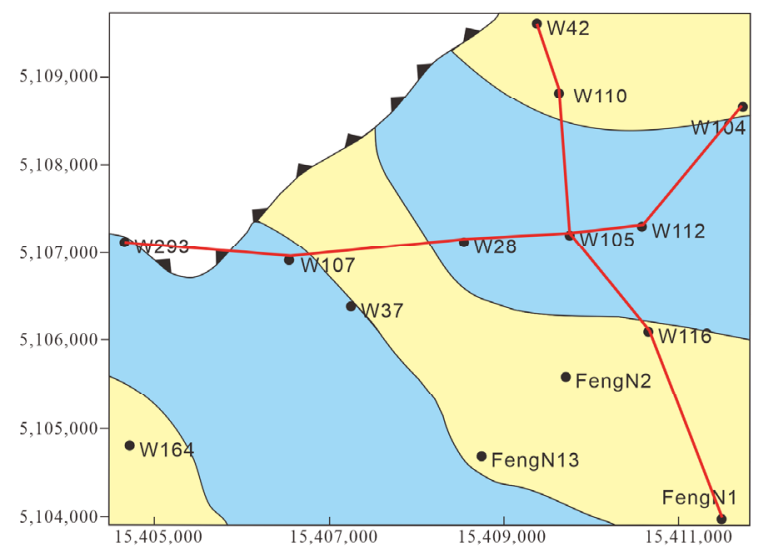

(c)

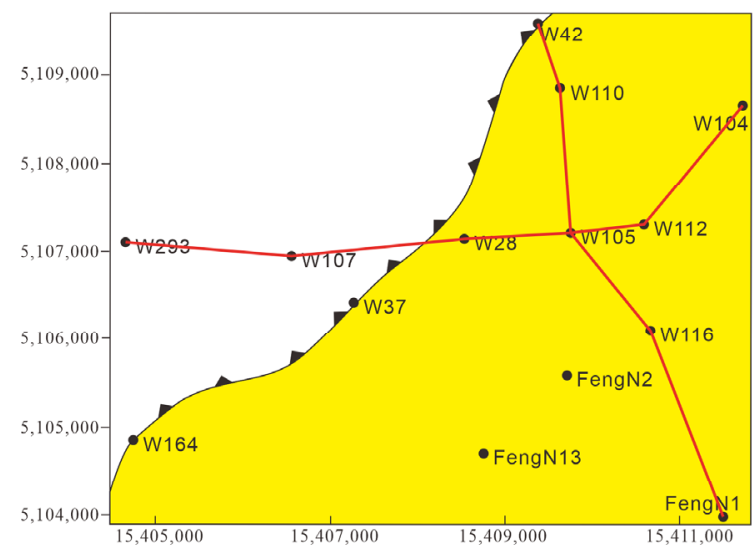

(e)

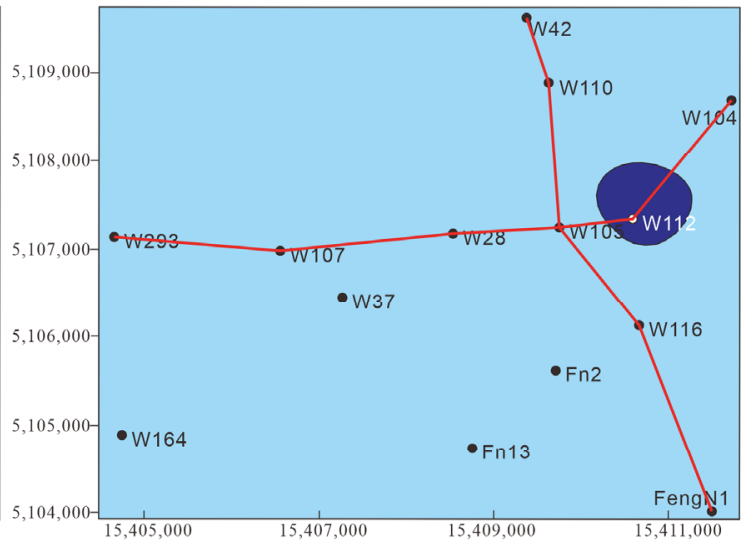

(b)

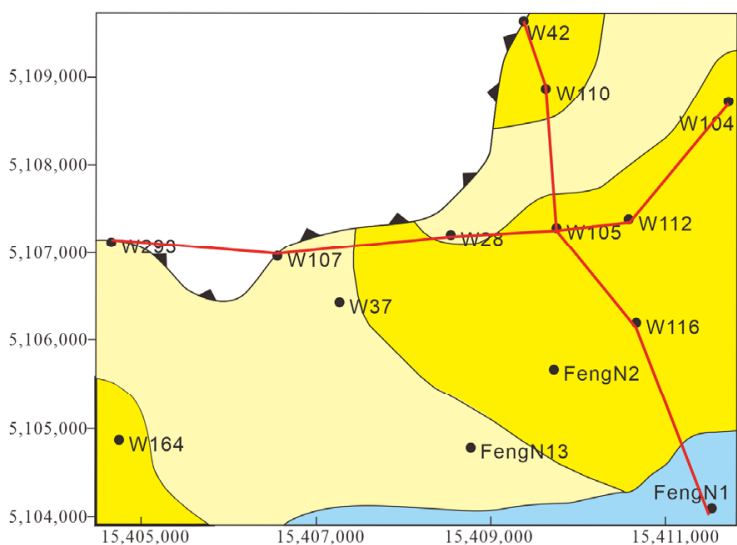

(d)

Legend

OW105 Well

Pinchout Line

Well Section
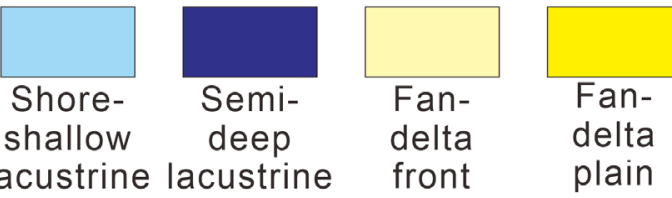

Figure 11. Planar view of the sedimentary facies of Jurassic strata in the study area: (a) Badaowan Formation; (b) Sangonghe Formation; (c) Xishanyao Formation; (d) Toutunhe Formation; (e) Qigu Formation.

\subsection{Sangonghe Formation}

During the sedimentary period of the Sangonghe Formation, the lacustrine area was further expanded from a transgressive system tract to a high-water-level system tract. According to the net to gross ratio, it can be inferred that the provenance at this time was in the north-by-west direction, which is a unidirectional provenance (Figure 10b). The 
high net to gross ratio in the study area is distributed near W42, and there are mainly small-scale semi-deep lacustrine sediments near W112. Shore-shallow lacustrine subfacies are widely distributed, mainly developing argillaceous shore-shallow lacustrine and sandy shore-shallow lacustrine. Mud plain and sand plain deposits are occasionally seen, which are viewed as the sedimentary environment of a short low-water-level period (Figure 11b).

\subsection{Xishanyao Formation}

The Xishanyao Formation is a Middle Jurassic formation. In terms of stratigraphic thickness, the thickness of the Xishanyao Formation ranges from 90-110 $\mathrm{m}$ in the crosssection from Well W28 to Well W104, and Well FengN1 is the thickest in the longitudinal section; both are generally in line with the pattern. From the east to the west of the study area, the thickness of the Xishanyao Formation, the thickness of the sandstone and the net to gross ratio all decrease gradually. This is caused by the uplift and denudation of the western crust. The area with a net to gross ratio below $30 \%$ is classified as shore-shallow lacustrine facies in combination with the cross-sectional comparison map of well-connected sedimentary facies and the plan of the net to gross ratio (Figure 10e). The area with net to gross ratio above $30 \%$ represents the sedimentary subfacies of the fan-delta front, and the sedimentary facies distribution map of the Xishanyao Formation (Figure 10c) was prepared by integrating the single-well logging facies and seismic profile data.

From Figure 10c, it can be seen that the eastern portion of the study area was basically stable in deposition during the Xishanyao Formation period, and miscellaneous colored mudstones appeared in Wells W42 and W110, which are relatively high in sand, indicating that the northeastern portion of the study area was primarily deposited at the fan-delta front at this time. The overall scope of the lacustrine basin shrank, and the fan-delta advanced from northeast to south. At this time, affected by the Yanshan movement, the northwestern portion of the study area suffered uplift and denudation, resulting in the absence of this formation near W293, that is, the northwestern portion of the study area. The formation of Well W107 is thin. Near Well W28, interbedding of gray mudstone and silty mudstone occurred in the Xishanyao Formation, which was the product of shore-shallow lacustrine. Therefore, a small portion of the lacustrine basins with shallower water bodies and smaller scales developed on both sides of the diagonal of the study area.

\subsection{Toutunhe Formation}

The sandstone thickness in the northwestern portion of the study area is low due to denudation caused by crustal uplift, and the net to gross ratio is relatively high in the planar view (Figure 10d). Combined with the comparison of the sedimentary facies profiles of the wells, the area with net to gross ratio above $40 \%$ is classified as the fan-delta plain subfacies; above $20 \%$ and below $40 \%$ represent the fan-delta front sedimentary subfacies. The subfacies, combined with the single-well log facies and seismic profile data, was used to compile the sedimentary facies distribution map of the Toutunhe Formation (Figure 11d).

From the contour map of the net to gross ratio, it can be seen that the area with a high net to gross ratio is concentrated near the FengN2 and W116 Wells. The lithology consists of gray siltstone and gravelly, coarse sandstone with mudstone, gradually transitioning to fan-delta plain. In the vicinity of Well W28, a low net to gross ratio appears, where the lithology is mainly mixed-color mudstone interbedded with brown-gray muddy fine sandstone, and the color of mudstone is mostly green-gray and brown, which is indicative of the depositional environment of the fan-delta front. The fan-delta range becomes larger, and most of the area in the eastern portion of the study area is fan-delta plain deposition. Because of the stratigraphic uplift in the northwest, debris in the direction of the northwest topographic highs is also involved in the sediment filling of the Toutunhe Formation.

\subsection{Qigu Formation}

The stratigraphy was mostly denuded in the northwestern area during the Qigu Formation period, except that the sandstone grew thicker in the whole area. The net to 
gross ratio was mostly above $20 \%$, with a high value in Well W110, and three net to gross ratio in Wells W104 and FengN1 were concentrated in the northeastern portion of the study area (Figure 10e). The material source was mainly the eastern or northeastern area at this time. The red mudstone and gray-white medium sandstone or gray sand conglomerate interbeds are mainly distributed in the Qigu Formation in the area. Combined with the net to gross ratio, the net to gross ratio in the study area decreases in a fan-like manner in the southeast to the northwest; the lacustrine basin is highly undeveloped, and the overall environment changes from wet to arid, indicating that it is in a fan-delta plain oxidative environment at this time (Figure 11e).

\subsection{Jurassic Sedimentary Evolutionary Features}

The sedimentary evolution of the area during the Jurassic period is roughly divided into several stages by combining the net to gross ratio distribution map and the sedimentary facies map of each formation.

During the Badaowan Formation depositional period, the Late Jurassic, the lacustrine basins that developed in the Fengcheng City Wuerhe area at this time were smaller in size. The lacustrine basins are even smaller in the study area, developing only to a small extent in the south, while the climate was more humid. The source of material comes from the northwest, and sometimes a small portion comes from the northeast. The sedimentary facies of the study area as a whole is fan-delta front. The development of several sets of channel sand bodies with good continuity can be observed on the continuous well profiles.

During the Late Jurassic, the area from the Badaowan Formation to the Sangonghe Formation belongs to the transgressive system tract. During the Sangonghe Formation, the water level rose to the maximum in the early stage and entered the high-water-level system tract. At this time, the sedimentary environment changed into a lacustrine environment, which specifically reflected the shore shallow lacustrine, and there was a small range of semi-deep lacustrine in the eastern region.

In the later stage, the water level decreased, and the water depth became shallow. The water retreated from the short, high-water-level system tract. At this time, to the Xishanyao Formation, the water level decreased, the fan-delta moved forward, and the lacustrine facies retreated to the southern small region. Additionally, the crust was uplifted in the northwestern portion of the study area, and tectonic movement caused the lack of stratum denudation.

During the period of the Toutunhe Formation, which is Middle Jurassic, stratigraphic uplift and denudation were intense, and the denudation range became larger than that of the Xishanyao Formation. During this period, the water retreat continued, the fan-delta front and plain subfacies developed, and a small area of shore and shallow lacustrine developed in the southeast until the end of the water retreat in the Qigu Formation.

The overall sedimentary facies development of the Qigu Formation is mainly fan-delta plain, the microphase is mainly developed with Underwater distributary channel and inter-channel fine-grained deposition, and the channel deposited thick layers of sand and gravel, which is the main feature of the deposition of the Qigu Formation. At the Early Jurassic, the low-water-level system domain is developed.

\subsection{Inspiration of Oil and Gas Reservoir Distribution}

Oil and gas reservoirs are inextricably linked to the sand distribution, and the reservoirs are mainly rocks with porosity and permeability, including sandstone and carbonate. In the northwest margin area, since the Mesozoic mainly developed terrestrial lacustrine basins, the main reservoirs are clastic rocks with relatively good porosity (distribute at $5.1-31.4 \%$, with average value $20.2 \%$ ) and permeability (distribute at $0.025-7539.37 \mathrm{mD}$, with average value $10.56 \mathrm{mD}$ ).

The fan-delta sedimentary system mainly developed in the study area has a facilitating effect on reservoir development. The reservoir sand bodies are mainly spatially continuous sandstones, such as underwater distributary channels in the delta plain and delta front. 
Multiple fan-delta sedimentary systems are developed in the area before and after, and spatially superimposed channel sand bodies are a good choice for the reservoir.

According to the spreading profile of connecting wells, porous and permeable channel sand bodies with good continuity are mainly distributed in the Badaowan Formation and the Qigu Formation. In the process of oil and gas testing, an 8-meter-thick oil layer was found in the Badaowan Formation of Well W118, and the comprehensive interpretation of the Badaowan Formation of Well W163 is that it contains a dry oil layer. There are four sections of oil-water colayers in the Badaowan Formation of Well W161, and there is a small section of reservoir interpretation in Well W29. Therefore, combining the oil and gas test results of each well and the comprehensive logging results, sand bodies favorable to the reservoir may be numerous in the Badaowan Formation. The reservoir type is mainly a tectonic-lithologic oil and gas reservoir; faults and lithology are the main factors controlling the reservoir distribution.

\section{Conclusions}

Based on previous research results combined with well logs and other data in the study area, we conducted a detailed stratigraphic mapping of the region. Two cross-sections were selected, and 10 wells were analyzed in single and continuous facies to spatially grasp the sand body distribution. Finally, net to gross ratio planar contour maps of the Jurassic formations were drawn to analyze the source and sand body planimetric distribution in each period. Furthermore, the sedimentary facies distribution map was also drawn to predict the sedimentary evolution in the sedimentary period of the study area. The following conclusions are drawn:

1. The Badaowan, Sangonghe and Xishanyao Formations of the Jurassic are commonly developed in the study area. The Toutunhe Formation and the Qigu Formation are uplifted and eroded in the northwest region.

2. Based on the combination of lithology and well logs, it can be predicted that the sedimentary sub-facies of Badaowan Formation is mainly fan-delta front, the Sangonghe Formation is primarily shore-shallow lacustrine, the Xishanyao Formation is fan-delta front and shore-shallow lacustrine deposit, and the Toutunhe Formation is fan-delta front and fan-delta plain, whose dominant facies are fan-delta plain. Finally, the Qigu Formation is mainly fan-delta plain.

3. The Jurassic Wuerhe area is mainly a system tract of transgression, high water level, regression and low water level. The Badaowan Formation embodies a transgressive system tract. The early Sangonghe Formation was a short, high-water-level system tract, and the water body became shallower in the later stage and then gradually retreated in the later stage of the Toutunhe Formation. During the period of the Qigu Formation, a large area of plain developed again and then entered the low-water-level system tract, forming a complete cycle.

Author Contributions: Conceptualization, S.L., and Y.L.; methodology, S.L., and Y.L.; software, S.L., and Y.L.; validation, S.L., and Y.L.; formal analysis, S.L., and Y.L.; investigation, S.L., and Y.L.; resources, S.L., and Y.L.; data curation, S.L., and Y.L.; writing-original draft preparation, S.L., and Y.L.; writing—review and editing, S.L., and Y.L.; visualization, S.L., and Y.L.; supervision, S.L., and Y.L.; project administration, S.L., and Y.L.; funding acquisition, S.L., and Y.L.; All authors have read and agreed to the published version of the manuscript.

Funding: The work was supported by the funding of Major National Science and Technology Projects of China (2016ZX05037-006-005) and project of R\&D Department of Petrochina (No. 2021DJ2005). The APC was supported by the funding of Major National Science and Technology Projects of China (2016ZX05037-006-005) and project of R\&D Department of Petrochina (No. 2021DJ2005).

Data Availability Statement: The data used to support the findings of this study are included within the article. 
Acknowledgments: The work was supported by the funding of Major National Science and Technology Projects of China (2016ZX05037-006-005) and project of R\&D Department of Petrochina (No. 2021DJ2005).

Conflicts of Interest: The authors declare that there are no conflict of interest regarding the publication of this paper.

\section{References}

1. Zhang, J. Research of Sedimentary Facies of Jurassic Badaowan Formation in Zhong18 Wells Block in Fengcheng Oilfield; Yangtze River University: Jingzhou, China, 2013.

2. Liu, Y.; Ma, X.; Zhang, X.; Guo, W.; Kang, L.; Yu, R.; Sun, Y. Shale gas well flowback rate prediction for Weiyuan field based on a deep learning algorithm. J. Pet. Sci. Eng. 2021, 203, 108637. [CrossRef]

3. Liu, Y.; Liu, S.; Pan, M.; Lei, Z. Research of Crustal Stress Simulation Using Finite Element Analysis Based on Corner Point Grid. Acta Sci. Nat. Univ. Peking 2019, 55, 643-653. [CrossRef]

4. Liu, Y.; Liu, S.; Pan, M. Finite element simulation of oil and gas reservoir in situ stress based on a 3D corner-point grid model. Math. Problems Eng. 2020, 2020, 7384085. [CrossRef]

5. Zhang, R. Study on Sequence Stratigraphy and Sedimentary Facies of the Lower Jurassic Badaowan Formation in the Northwest of the Junggar Basin; Chengdu University of Technology: Chengdu, China, 2016.

6. $\quad$ Liu, Y.; Pan, M.; Liu, S.; Shi, Y.; Dong, Y.; Zhang, Z.; Wang, Y. Comprehensive Depositional System and Reservoir Characterization Study of Chang 4+5 Reservoir of Yanchang Group, Infill Well Region in Baiyushan Area, Ordos Basin. Acta Sci. Nat. Univ. Peking 2018, 54, 1028-1038. [CrossRef]

7. Qi, L.; Bao, Z.; Wu, B.; Li, W.; Yuan, L. Distribution and sequence stratigraphic framework of the Jurassic strata on the northwestern margin of the Junggar Basin. Oil Gas Geol. 2008, 29, 261-267. [CrossRef]

8. Zhang, S. 18 Well Area of Fengcheng Oilfield of Qigu Formation of Jurassic of Sedimentary Facies Research; Yangtze River University: Jingzhou, China, 2016.

9. Wei, S. Comprehensive Study on Petroleum Geology in the Northwest of Junggar Basin; Southwest Petroleum Institute: Chengdu, China, 2002.

10. Lei, Z.; Bian, D.; Du, S.; Wei, Y.; Ma, H. Characteristics of fan forming and oil-gas distribution in west-north margin of Junggar Basin. Acta Pet. Sin. 2005, 26, 8-12. [CrossRef]

11. Sui, F. Tectonic Evolution and Its Relationship with Hydrocarbon Accumulation in the Northwest Margin of Junggar Basin. Acta Geol. Sin. 2015, 89, 779-793. [CrossRef]

12. Hu, Z.; Li, M. Sequence Modeling and Sedimentary Facies Evolution of Jurassic In Northwestern Edge of Junggar Basin. Oil Gas Geol. 2003, 24, 351-355. [CrossRef]

13. Yu, Y.; Li, D.; Hu, S.; Lei, Z.; He, D. Fans Sedimentation and Exploration Direction of Fan Hydrocarbon Reservoirs in Foreland Thrust Belt of the Northwestern Junggar Basin. Acta Geosci. Sin. 2007, 28, 62-71. [CrossRef]

14. Qu, J.; Qiu, Y.; Shi, Z.; Gao, W. Fault Activities and Hydrocarbon Accumulation in Wu-Xia Fault Belt in Northwestern Margin of Junggar Basin. Xinjiang Pet. Geol. 2007, 28, 403-405. [CrossRef]

15. Du, S. Research on the Foreland Thrust Belt and on the Accumulation of Petroleum in the North-Western Margin of the Jungger Basin, China; Guangzhou Institute of Geochemistry, Chinese Academy of Sciences: Guangzhou, China, 2005.

16. Yin, X. Sedimentary Facies Characteristics of Jurassic Badaowan Formation in Northwestern Edge of Junggar Basin-Take the Northern Section of the Fault Zone of Kebai for Example; Xinjiang University: Ürümqi, China, 2013.

17. Yang, H.; Chen, S.; Yang, J.; Wu, C. Sequence Division and Stratigraphic Evolution of Jurassic in Wu-Xia Area, Junggar Basin. Xinjiang Pet. Geol. 2007, 28, 437-440. [CrossRef]

18. Luo, T. Research of Sedimentary Facies Evolution of Jurassic in Wuerhe-Xiazijie Area in the Northwestern Edge of Junggar Basin; Xinjiang University: Ürümqi, China, 2015.

19. Luo, Y. Study on Characteristics of Sedimentary Facies and Reservoir at Jurassic Xishanyao Formation of Mid Block-3 in Junggar Basin Chengdu University of Technology: Chengdu, China, 2008.

20. Zhang, C.; Zhu, R.; Yin, T.; Yin, Y. Advances in Fan Deltaic Sedimentology. Xinjiang Pet. Geol. 2015, 36, $362-368$.

21. Abu-Hashish, M.F.; Ali, S.B. Integration of well logs and seismic data for facies analysis and modelling of the El-Wastani Formation in the Sequoia Gas Field, offshore Nile Delta, Egypt. J. Afr. Earth Sci. 2021, 183, 104343. [CrossRef]

22. Li, Y.; Fan, A.; Yang, R.; Sun, Y.; Lenhardt, N. Sedimentary facies control on sandstone reservoir properties: A case study from the permian Shanxi Formation in the southern Ordos basin, central China. Mar. Pet. Geol. 2021, 129, 105083. [CrossRef]

23. Xu, H.; Chen, J.; Cui, Z.; Chen, R. Sedimentary facies and depositional processes of the Diexi ancient dammed lake, upper Minjiang river, China. Sediment Geol. 2019, 398, 105583. [CrossRef]

24. Silvestre, C.P.; da Silva, A.L.C.; da Silva, M.A.M.; Baptista Neto, J.A.; Parolin, M.; Macario, K.C.D.; de Souza, R.C.C.L.; Fernandez, G.B.; Amaral, D.F. Sedimentary facies and Holocene depositional evolution of the Maricá Lagoon, Rio de Janeiro, Brazil. J. S. Am. Earth Sci. 2021, 111, 103438. [CrossRef]

25. Davies, S.; Stow, D.; Nicholson, U. Late glacial to holocene sedimentary facies of the Eirik Drift, southern Greenland margin: Spatial and temporal variability and paleoceanographic implications. Mar. Geol. 2021, 440, 106568. [CrossRef] 
26. Han, F.; Zhang, H.; Rui, J.; Wei, K.; Zhang, D.; Xiao, W. Multiple point geostatistical simulation with adaptive filter derived from neural network for sedimentary facies classification. Mar. Pet. Geol. 2020, 118, 104406. [CrossRef]

27. Basu, H.; Dandele, P.S.; Srivastava, S.K. Sedimentary facies of the Mesoproterozoic Srisailam Formation, Cuddapah basin, India: Implications for depositional environment and basin evolution. Mar. Pet. Geol. 2021, 133, 105242. [CrossRef]

28. Liu, Y.; Zhang, X.; Shi, J.; Guo, W.; Kang, L.; Yu, R.; Sun, Y.; Wang, Z.; Pan, M. A reservoir quality evaluation approach for tight sandstone reservoirs based on the gray correlation algorithm: A case study of the Chang 6 layer in the $W$ area of the as oilfield, Ordos Basin. Energy Explor. Exploit. 2021, 39, 1027-1056. [CrossRef]

29. Fang, Z. The Application of Log Facies General Analysis in Lithologic Gas Sdimentary Facies and Reservoir Prediction; China University of Geosciences: Beijing, China, 2012.

30. Liu, J.; Zhang, Q.; Lian, D.; Xie, F.; Wu, Z.; Cao, D. Application of logging facies in sedimentary microfacies analysis of single well-Taking the division of sedimentary microfacies of borehole 34-1 in No. 4 well field of sulfur ditch mining area in the southern margin of Junggar Basin as an example. In Proceedings of the 13th National Conference on paleogeography and Sedimentology, Beijing, China, 25 October 2014.

31. Jiao, Y.; Zhou, H.; Zhuang, X.; Liu, S.; Yang, S.; Ma, M. Fan deltaic depositional systems and their relationship to oil and gas accumulation. Acta Sedimentol. Sin. 1998, 16, 70-75. [CrossRef]

32. Jiao, L. Approaches of sedimentary facies analysis based on well logs. China Pet. Chem. Stand. Qual. 2014, 34, 198. [CrossRef]

33. Wu, J.; Luo, Y.; Li, C. Comparative study on identification marks and characteristics of fluvial sedimentary facies. J. Oil Gas Technol. 2009, 31, 177-179. 